\title{
Statistical modeling of ruminal pH parameters from dairy cows based on a meta-analysis
}

\author{
A. Mensching, ${ }^{1 *} \odot$ J. Hummel, ${ }^{2}$ and A. R. Sharifi ${ }^{1}$ \\ ${ }^{1}$ Animal Breeding and Genetics Group, Department of Animal Sciences, Center for Integrated Breeding Research, University of Goettingen, \\ 37075 Goettingen, Germany \\ ${ }^{2}$ Ruminant Nutrition Group, Department of Animal Sciences, University of Goettingen, 37077 Goettingen, Germany
}

\section{ABSTRACT}

Adequate feeding of high-performance dairy cows is extremely important to avoid the digestive disorder subacute ruminal acidosis. Subacute ruminal acidosis is defined as a status with a below-average ruminal $\mathrm{pH}$ that does not cause direct clinical symptoms at the individual level but is relevant for animal welfare due to a higher risk of secondary health problems at the herd level. The main objective of this study was to apply meta-analytical methods in an exploratory approach to investigate the association between $\mathrm{pH}$ parameters of the ventral rumen with milk and diet parameters. Data from 32 studies using continuous $\mathrm{pH}$ measurement in the ventral rumen of lactating cows were included in the meta-analysis. Available information extracted from all studies was categorized into parameters associated with management, cow, diet, milk, and $\mathrm{pH}$. The statistical analysis was divided into 4 sections. First, a multiple imputation procedure based on a principal component model was applied, since approximately $19 \%$ of the data set consisted of missing values due to heterogeneity in provided information between the studies included in the analysis. In a second step, all potential predictors for the $\mathrm{pH}$ parameters, including the daily mean $\mathrm{pH}$, the time with a $\mathrm{pH}$ below 5.8 , and the $\mathrm{pH}$ range, were examined for their prediction suitability using multi-level mixed effects meta-regression models. These analyses were performed on the raw and the imputed data. Because the results of both approaches were consistent, the imputing procedure was considered to be appropriate. Third, automated variable selection was applied to all $3 \mathrm{pH}$ parameters separately for the predictor groups milk and diet using the imputed data set. Thereby, multi-model inference was used to estimate the relative importance of the selected variables. Finally, a functional relationship between the

Received April 15, 2019

Accepted September 13, 2019.

*Corresponding author: andre.mensching@uni-goettingen.de
$3 \mathrm{pH}$ parameters was established. The fat to protein ratio of milk, milk fat, and milk protein showed significant associations in meta-regression analysis for all 3 $\mathrm{pH}$ parameters when used as a single predictor. Out of the group of diet-specific variables, the acid detergent fiber, neutral detergent fiber, nonfiber carbohydrate, starch content, as well as the forage to concentrate ratio, showed the highest significance in the models. In particular, the multi-model inference showed that the protein, fat, and lactose content of the milk can best quantify the association to the daily mean $\mathrm{pH}$ and the time with a $\mathrm{pH}$ below 5.8 in a multiple regression model.

Key words: ruminal $\mathrm{pH}$, subacute ruminal acidosis, meta-regression, statistical modeling

\section{INTRODUCTION}

Adequate nutrition is a major challenge in milk production, where a compromise between sufficient energy and fiber supply is essential. High-performance dairy cows require high-energy feed, typically based on carbohydrates from grain. However, this increases the risk for the digestive disorder SARA, which is often found in high-yielding herds (Nocek, 1997). The risk for the clinical manifestation of this digestive disorder is increased especially in the first month of lactation (Gröhn and Bruss, 1990). The subacute form of ruminal acidosis shows no or no distinctive individual clinical signs and symptoms on the individual level, but impairs animal welfare in the long run and can cause economic losses (Nocek, 1997). The main reasons are associations with various clinical symptoms at the herd level, including reduced feed intake, lower milk production efficiency, a higher risk for diarrhea and hoof diseases, as well as an overall higher culling rate (Nocek, 1997; Kleen et al., 2003). Therefore, Enemark (2008) claimed SARA to be the most important nutritional disorder of dairy cattle. Denwood et al. (2018) found that reticular $\mathrm{pH}$ profiles are farm as well as animal specific and follow a predictable pattern in the course of the day; devia- 
tions from these specific profiles could be associated with reduced productivity. Bramley et al. (2008), who clustered observations from a total of 100 farms into 3 categories based on rumenocentesis $\mathrm{pH}$, VFA, and ammonia concentrations, could not detect a decrease in milk yield in the category with the lowest $\mathrm{pH}$ values, but identified significant lower milk fat contents and lower milk fat to milk protein ratios (FPR).

The direct indicator for SARA is generally the ruminal $\mathrm{pH}$, which is associated with fermentation properties (Enemark et al., 2002). A drop in pH is primarily the result of an accumulation of short-chain fatty acids due to a high amount of fermentable carbohydrates (Nocek, 1997; NRC, 2001). Associations between changes in the feeding regimen and the ruminal $\mathrm{pH}$ have been known for a long time and were already determined by Johnson and Sutton (1968) using a continuous $\mathrm{pH}$ measurement in the ventral rumen of dairy cows. In addition, Fulton et al. (1979) observed adapting feeding behavior and subsequent $\mathrm{pH}$ changes on steers depending on alterations in diet composition.

Genetics and thus animal individuality can also play an important role in an animal's susceptibility to SARA. For example Golder et al. (2018), who worked with acidosis-challenged dairy heifers, observed large between-animal variance with regards to clinical signs of acidosis, rumen characteristics, and the ruminal microbiome. In a genome-wide association study, the authors were able to identify genetic markers and candidate genes for ruminal phenotypes such as the ratio of acetate to propionate. Therefore, one could hypothesize that the individual ruminal absorption capacity of fermentation products can vary between animals when regulated by genetic makeup and thus influence ruminal $\mathrm{pH}$ development.

The major challenge in diagnosing this digestive disorder is to identify a precise phenotype for SARA. In previous studies, $\mathrm{pH}$ thresholds were defined as an indication of SARA, but these thresholds vary among studies. Zebeli et al. (2008) stated that it seems to be a "matter of individual choice" (page 2047) to define a $\mathrm{pH}$ threshold for SARA. Consequently, there is no widely accepted description of a phenotype for SARA.

In a meta-analysis, Zebeli et al. (2008) related the ruminal daily mean $\mathrm{pH}(\overline{\mathbf{p H}})$ to the squared physically effective NDF retained on a 1.18-mm sieve (peNDF > 1.18) and negatively to ruminally degradable starch from grain and DMI. Additionally, they derived thresholds for $\overline{\mathrm{pH}}$ and the average daily time with $\mathrm{pH}<5.8$ $(\mathbf{T p H}<5.8)$ from studies of cattle challenged with SARA. It was concluded that $\overline{\mathrm{pH}}$ should be higher than 6.16 and $\mathrm{TpH}<5.8$ should not exceed $5.24 \mathrm{~h} / \mathrm{d}$ to decrease the incidence probability of SARA. These thresholds are predominantly used in agricultural science, due to the fact that the measurement of ventral ruminal $\mathrm{pH}$ requires expensive technical equipment and ruminally fistulated cows. Other studies investigating the prevalence of SARA on a farm level have used a $\mathrm{pH}$ of 5.5 as threshold to define SARA by applying a noncontinuously $\mathrm{pH}$ measurement via rumenocentesis (Nordlund et al., 1995; Garrett et al., 1999). In agricultural practice, the FPR with values $<1.0$ is also commonly used as an indicator for SARA (Enemark et al., 2002). The protein and fat content of milk depend on lactation stage (Stanton et al., 1992), which influences the FPR (Buttchereit et al., 2010), thus limiting the use of a fixed FPR threshold as an indicator for SARA at the individual level. Further, milk fat content can be significantly reduced by dietary intake of PUFA independent of any effect on ruminal $\mathrm{pH}$ (Harvatine and Allen, 2006a,b).

The main objective of this study was to investigate the association between ruminal $\mathrm{pH}$ parameters of the ventral rumen of fistulated cows, and milk- and diet-specific parameters through an exploratory metaanalysis approach. The focus was on milk-specific traits to determine better indicators for SARA.

\section{MATERIALS AND METHODS}

\section{Search for Published Literature}

A comprehensive literature search was carried out to identify studies characterized by automated and continuous data acquisition of the $\mathrm{pH}$ in the ventral rumen of lactating dairy cows. Studies were of relevance if either different diets were fed or if the frequency of feed offered was varied using the same diet.

Within the database query the search terms "ruminal pH," "continuous measurement," "acquisition system," "sub-acute ruminal acidosis," "SARA," "lactating cows," "dairy cows" as well as combinations of these were used. The literature search was conducted using 2 search engines, Google Scholar (http://scholar .google.com/) and Web of Science (http://apps .webofknowledge.com). Furthermore, the search function on the websites of Journal of Dairy Science (http:/ /www.journalofdairyscience.org/) and Animal (https:/ /www.cambridge.org/core/journals/animal) were used. The references of other meta-analyses that were carried out in the same research field in the past were another important source, for example the studies of Zebeli et al. (2008) and White et al. (2017a,b). Journal articles already identified and selected for meta-analysis were examined for further references if titles indicated the same research topic. Only studies published in English 


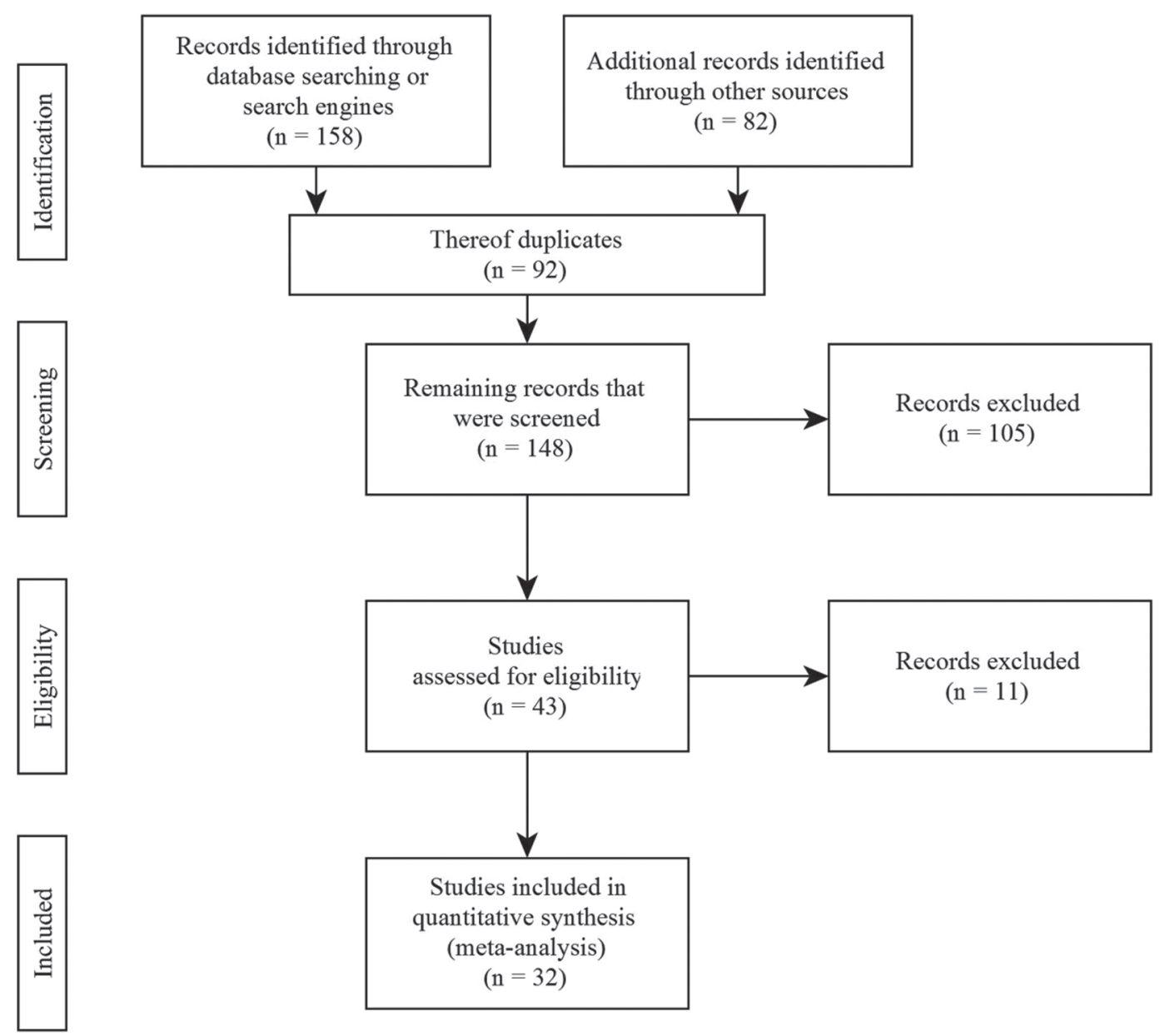

Figure 1. PRISMA flowchart according to Moher et al. (2009) describing the systematic search for published literature.

were considered. The process of data collection is visualized in Figure 1 using a PRISMA flowchart according to Moher et al. (2009). The flowchart was created using the yEd graph editor (yWorks GmbH, 2019).

\section{Inclusion and Exclusion Criteria}

The selection of studies was based on pre-defined criteria. In total, 148 studies were identified. First, they were screened to see if the continuous measurement of $\mathrm{pH}$ and dairy cows was the subject of investigation. Studies with discontinuous $\mathrm{pH}$ measurement were excluded because a very broad spectrum of methods is available, consisting of various sampling techniques, sample times, and frequencies or different sample locations in the rumen. These diverse methods could undoubtedly have an effect on the measured $\mathrm{pH}$ values, as already described by Lane et al. (1968) in the case of different sampling locations in the rumen. Previous meta-analyses, for example by Zebeli et al. (2008) and White et al. (2017a,b), considered both continu- ous and discontinuous $\mathrm{pH}$ measurements. Due to the aforementioned heterogeneity of the methods used for discontinuous measurements, this approach bears the risk of distorting the results. Therefore, the focus in this study was exclusively on studies with continuous $\mathrm{pH}$ measurements for at least $24 \mathrm{~h}$ in the ventral rumen of fistulated lactating cows. Additionally, studies were excluded if other species (sheep, goats) or males (steers) were examined or if the $\mathrm{pH}$ was measured in the reticulum. After the initial screening, 43 remaining studies were assessed for eligibility.

In the following step, studies were excluded from further analysis if the diet was supplemented with PUFA due to the fact that such treatments have been shown to cause a significant milk fat depression, which could create a statistical bias (Bauman and Griinari, 2003; Harvatine and Allen, 2006a). Another exclusion criterion was the use of fermentation modifiers such as Monensin and Fermenten or the dietary supplementation of essential oils, fibrolytic enzymes, and sodium bicarbonate in at least one treatment of a study to reduce potential 
Table 1. Studies used in the meta-analysis

\begin{tabular}{lll}
\hline Reference & & \\
\hline AlZahal et al., 2007 & Krause et al., 2002a,b & Sullivan et al., 2012 \\
AlZahal et al., 2009 & Krause and Combs, 2003 & Sun and Oba, 2014 \\
Beauchemin et al., 2003 & Krause et al., 2003 & Taylor and Allen, 2005a,b,c \\
Beauchemin and Yang, 2005 & Longuski et al., 2009 & Voelker and Allen, 2003a,b \\
Bhandari et al., 2008 & Macmillan et al., 2017 & Yang and Beauchemin, 2006a,b \\
Chibisa et al., 2015 & Maekawa et al., 2002a,b & Yang and Beauchemin, 2006c \\
Dann et al., 2014 & Oba and Allen, 2000a,b & Yang and Beauchemin, 2007a,b \\
Dann et al., 2015 & Penner and Oba, 2009 & Yang and Beauchemin, 2009 \\
Farmer et al., 2014 & Rustomo et al., 2006a & Zhang et al., 2010b \\
Hassanat et al., 2013 & Rustomo et al., 2006b & Zhang et al., 2010a \\
Jiang et al., 2017 & Silveira et al., 2007 & \\
\hline
\end{tabular}

bias. Furthermore, studies were excluded if the statistical analysis was contestable or the statistics relevant for the meta-analysis were not reported. The study by Yang et al. (2001) can be cited as an example, since the analysis was not based on a mixed effect model and results were only reported on a main effect basis. The final data set contains data from 32 experiments published between 2000 and 2017 (Table 1).

The experimental design of most included studies can be characterized by a single $(\mathrm{n}=4)$ or replicated $(\mathrm{n}=$ 21) Latin squares design. Additionally, 3 crossover and 4 case control studies were considered. Holstein cows were used in all experiments.

\section{Variables Extracted for Meta-Analysis}

In addition to the usual reported $\overline{\mathrm{pH}}$ in studies with continuous $\mathrm{pH}$ measurement, $\mathrm{TpH}<5.8$, the minimum and maximum $\mathrm{pH}$, as well as the $\mathrm{pH}$ range $(\boldsymbol{\Delta} \mathbf{p H})$ were collected. The minimum and maximum $\mathrm{pH}$, however, were used to estimate $\Delta \mathrm{pH}$ if it was not provided directly. The standard error of the mean (SEM) was recorded for all of the $\mathrm{pH}$ variables. The SEM is needed to determine the sample variance of the treatment means to weigh the treatments within the statistical modeling, as customary in a meta-analysis (see MultiLevel Meta-Regression section).

Furthermore, information on the different treatments, which in most studies corresponds to different diets, was collected. This includes energy content, forage and concentrate content, as well as other results of feed analyses, such as DM, CP, ether extract (EE), starch, NDF, ADF, peNDF > 1.18, physically effective NDF retained on an 8-mm sieve (peNDF $>8$ ), and NFC from the offered diets. Daily feeding frequency (DFF) was also captured as a management characteristic. In addition, information about the milk yield and the milk ingredients fat, protein, lactose, and MUN was collected from the studies.

The DMI was recorded as a cow specific parameter. Other animal specific variables like BW and the lacta- tion stage represented by DIM were initially discussed. However, the estimated treatment means refer to the entire experimental period lasting approximately 3 mo. Such a wide range of the lactation period makes DIM unsuitable for meta-analytical approaches. Even though the lactation stage is very important and significantly influences the DMI, milk yield, milk protein, milk fat, and FPR, its applicability in a meta-analytical approach is limited. Because BW is currently not routinely measured on commercial farms, it was not taken into account.

\section{Data Preparation and Calculations}

During data extraction, it became apparent that reported information was heterogeneous and that not all studies reported the same parameters. This also includes the fact that some studies reported the same variables in different measurement units, which therefore had to be standardized. For example, some reported $\mathrm{TpH}<5.8$ in hours per day (e.g., AlZahal et al., 2008), others in minutes per day (e.g., Jiang et al., 2017). This was unified by converting $\mathrm{TpH}<5.8$ and its SEM to hours per day. If studies provided average daily time with $\mathrm{pH}$ below 5.6 and $6.0, \mathrm{TpH}<5.8$ and its SEM were approximated by averaging these values (e.g., Bhandari et al., 2008). The difference between the minimum and maximum $\mathrm{pH}(\boldsymbol{\Delta} \mathbf{p H})$ was also calculated (e.g., Beauchemin and Yang, 2005). In such cases, the SEM was estimated as the mean of the SEM from the minimum and maximum $\mathrm{pH}$.

Information on diet composition was used to calculate $\%$ forage content if it was not reported directly (e.g., Zhang et al., 2010a). The forage to concentrate ratio $(\mathbf{F}: \mathbf{C})$ was calculated based on the percentage of forage and concentrate in the diet by dividing the forage by the concentrate content. If peNDF $>1.18$ or peNDF $>8$ were not reported directly, they were computed by multiplying the proportions of DM $>1.18$ and $>8 \mathrm{~mm}$ and the NDF content of the offered diet. In such cases, the particle size distributions were measured with 
a Penn State Particle Separator (e.g., Silveira et al., 2007) or a Analysette 3 (Fritsch, Oberstein, Germany) vertical oscillating sieving machine (Beauchemin et al., 2003).

In studies in which only the $\mathrm{NE}_{\mathrm{L}}$ intake per day was given instead of the $\mathrm{NE}_{\mathrm{L}}$ content of the diet, the $\mathrm{NE}_{\mathrm{L}}$ content was calculated by dividing the total energy intake by the DMI (e.g., Voelker and Allen, 2003a,b).

Another variable of interest was the FPR, which was calculated by dividing the milk fat content by the milk protein content. Additionally, the ECM yield was calculated after imputation using the formula from (Kirchgessner, 1987):

$$
\begin{aligned}
& \operatorname{ECM}(\mathrm{kg} / \mathrm{d})=\operatorname{milk}(\mathrm{kg} / \mathrm{d}) \\
& \times \frac{0.38 \times \operatorname{fat}(\%)+0.21 \times \operatorname{protein}(\%)+1.05}{3.28} .
\end{aligned}
$$

A special case was the study of AlZahal et al. (2009), where 2 treatments were used in a case-control study, but the results were given on a weekly basis over a period of $4 \mathrm{wk}$. For this reason, the mean value of all observations was determined for each treatment, so that only 2 instead of 8 observations were considered from this study. Due to this subsequent averaging, the SEM had to be divided by $\sqrt{4}$ because of the quadruplication of $n$.

Further, Rustomo et al. (2006a), Krause et al. (2002a,b, 2003), and Krause and Combs (2003) provided the standard error of the differences instead of the SEM for the estimated treatment means of the $\mathrm{pH}$ parameters. Therefore, the SEM was back-calculated by dividing the standard error of the differences by $\sqrt{2}$ (Roman-Garcia et al., 2016).

Three further variables had to be generated to consider the hierarchical data structure in the meta-analytical evaluation: a variable that records the overall affiliation of the individual treatments (study), a variable for a sub-cluster structure (sub-study) if the animals were divided into 2 groups in case control studies, and a unique identifier (id) for each individual treatment mean.

After data collection, all metric variables were first graphically examined using box plots to identify potential extreme values or outliers. In this respect, 2 studies showed conspicuous values. One of these is the study by Krause et al. (2002a,b), where nonphysiological lactose contents between 2.0 and $2.1 \%$ were reported. In the second study, diets with EE $>7 \%$ DM were fed (Hassanat et al., 2013). To minimize the probability of bias, the values of the respective affected variable were removed in both studies.
In total, 23 variables were captured from the studies, which can be categorized into 5 groups: management, cow, diet, milk, and $\mathrm{pH}$ parameters. Table 2 gives an overview with a statistical description of all groups and the variables contained.

\section{Statistical Analysis}

Multiple Imputation Based on a Principal Component Analysis Model. Due to the fact that the metabolism of dairy cows is a complex system, it can be assumed that several variables are required to build a statistical model capable to predict complex parameters such as $\overline{\mathrm{pH}}, \mathrm{TpH}<5.8$, and $\Delta \mathrm{pH}$. Missing values considerably restrict the analysis when using multiple regression models, since these models only work with complete observations of all variables in the model. An overview of missing values of the present data set for all 23 variables is given in Figure 2 by showing a modified matrix plot, which was created with the matrixplot function from the VIM (Templ et al., 2019) package. Even though the selection of variables focused on those that were provided by most of the studies, about $19 \%$ of the data across the 23 variables was missing. Variables without missing values were the frequency of daily feed offers, DMI, F:C, CP, $\mathrm{NDF}$, and $\overline{\mathrm{pH}}$. White et al. $(2017 \mathrm{a}, \mathrm{b})$ reported on the problem of missing values in their meta-analysis and solved it by assuming tabular values reported by the National Animal Nutrition Programme for unavailable information on chemical components of the diet before calculating the nutrient composition of the entire diet. In contrast to their approach, a multiple imputing procedure based on a multivariate principal component analysis (PCA) model using the MIPCA function from the missMDA (Husson et al., 2019) package in $\mathrm{R}$ ( $\mathrm{R}$ Core Team, 2018) was used in this study. The theory behind it has been described in detail by Josse and Husson (2016). Before the multiple imputation was performed, the number of main components had to be determined via cross validation using the estim_ncp$P C A$ function from the same package. In the MIPCA procedure 100 imputed data sets were created using the bootstrap method. After imputing, the FPR and the ECM were recalculated for the imputed observations.

The uncertainty of prediction can be derived based on the variance between the imputed values. In addition, the suitability of the imputations was examined in 2 ways. First, the distributions of the continuous variables before and after imputing were compared visually and with a 2-sample Kolmogorov-Smirnov test using the ks.test function in $\mathrm{R}$ ( $\mathrm{R}$ Core Team, 2018). Thereby, a test was carried out to determine whether 
each of the 2 samples are subject to the same continuous distribution. Second, the associations between the $3 \mathrm{pH}$ parameters and all individual potential predictors were analyzed using a multi-level meta-regression model for the raw incomplete data set as well as for the imputed data set. Then, the estimates of the regression coefficients of all models were compared for the 2 data sets.

Since the $\mathrm{TpH}<5.8$ and $\Delta \mathrm{pH}$ consisted of 13.4 and $28.6 \%$ of missing values, their SEM were estimated using the arithmetic mean of the recorded SEM of nonmissing observations.

Multi-Level Meta-Regression. The analysis with meta-regression models was performed using the rma. $m v$ function of the metafor (Viechtbauer, 2019a) package in $\mathrm{R}$ ( $\mathrm{R}$ Core Team, 2018). The multi-level mixed effect meta-regression models can be described as

$$
\begin{gathered}
y_{i j k}=\beta_{0}+\beta_{1} x_{i j k, 1}+\beta_{2} x_{i j k, 2}+\ldots+\text { study }_{k} \\
\quad+(\text { study } \times \text { sub-study })_{j k} \\
+(\text { study } \times \text { sub-study } \times \text { id })_{i j k}+e_{i j k},
\end{gathered}
$$

where $y_{i j k}$ is the effect size of the $i$ th treatment id, hierarchically nested in a sub-study ${ }_{j}$, which itself is nested in study $k$. This nesting structure is taken into account via the interaction terms (study $\times$ sub-study) ${ }_{j k}$ and (study $\times$ sub-study $\times$ id $)_{i j k}$. Concerning the fixed regression coefficients, $\beta_{0}$ corresponds to the intercept and $\beta_{1}, \ldots, \beta_{m}$ to the regression coefficients of the explanatory variables $x_{i j k, 1}, \ldots, x_{i j k, m}$. It was assumed that the random effects are independent and identically distributed to a normal distribution within $s t u d y_{k} \sim N\left(\mathbf{0}, \sigma_{1}^{2}\right), \quad(\text { study } \times \text { sub-study })_{j k} \sim N\left(\mathbf{0}, \sigma_{2}^{2}\right)$, (study $\times$ sub-study $\times \mathrm{id})_{i j k} \sim N\left(\mathbf{0}, \sigma_{3}^{2}\right)$, and $e_{i j k} \sim N\left(\mathbf{0}, v_{i}\right)$. In this meta-analytical approach, the sampling variance $v_{i}$ is assumed to be known and corresponds to the squared SEM of each effect size (i.e., the treatment mean of the $\mathrm{pH}$ parameter). The $\sigma_{1}^{2}, \sigma_{2}^{2}$, and $\sigma_{3}^{2}$ correspond to the variances of the random effects, which have to be estimated. In meta-analysis, the individual observations are usually weighted by their reciprocal of the sampling variance (Borenstein et al., 2009; Schwarzer et al., 2015; Viechtbauer, 2019a). Thus, treatments

Table 2. Statistical description of the data set

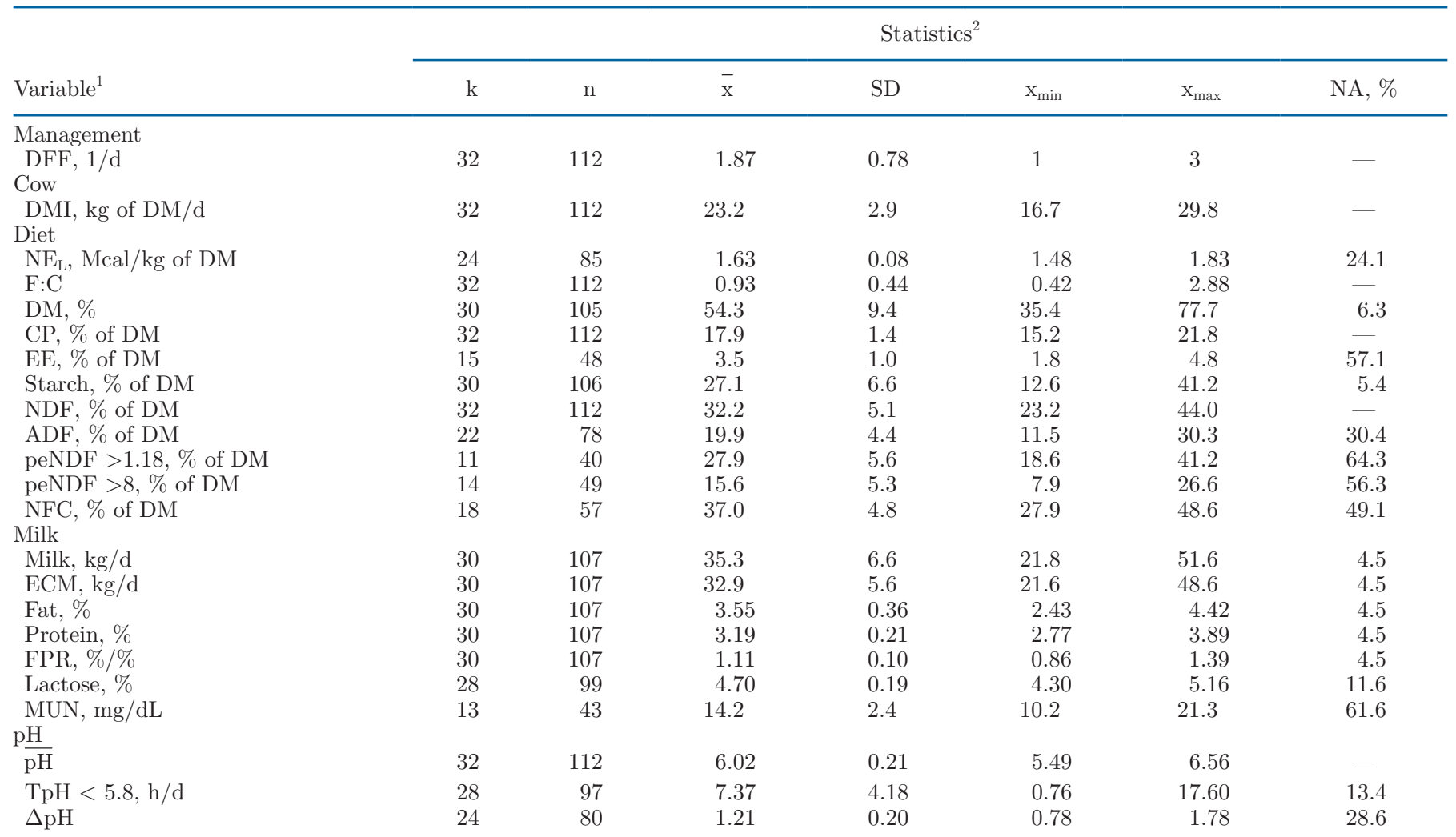

${ }^{1} \mathrm{DFF}=$ daily feeding frequency; $\mathrm{F}: \mathrm{C}=$ forage to concentrate ratio; $\mathrm{EE}=$ ether extract; $\mathrm{FPR}=$ fat to protein ratio; peNDF $>1.18$ and peNDF $>8=$ physically effective NDF retained on a 1.18- and 8-mm sieve, respectively; $\overline{\mathrm{pH}}=$ daily mean ruminal $\mathrm{pH} ; \mathrm{TpH}<5.8=$ average daily time with $\mathrm{pH}<5.8 ; \Delta \mathrm{pH}=\mathrm{pH}$ range.

${ }^{2} \mathrm{NA}=$ not available, missing values; $\mathrm{k}=$ number of studies; $\mathrm{n}=$ number of treatment means; $\overline{\mathrm{x}}=\operatorname{arithmetic}$ mean; $\mathrm{x}_{\min }=\operatorname{minimum} ; \mathrm{x}_{\max }=$ maximum. 


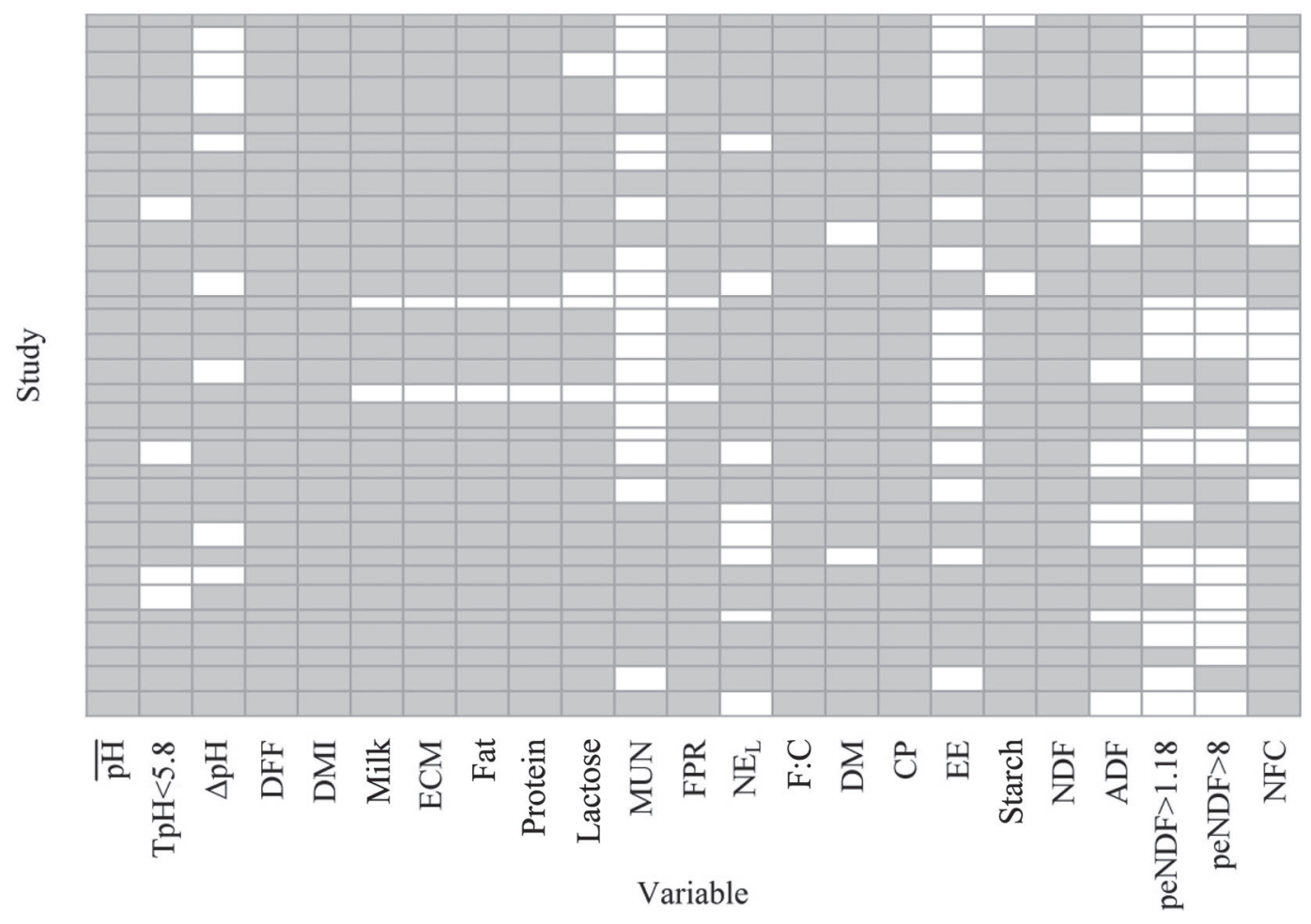

Figure 2. Visualization of data availability with a matrix plot (Templ et al., 2019). Gray rectangles show available data and white rectangles indicate missing values. The height of each rectangle is proportional to the number of treatment means of the respective study. DFF $=$ daily feeding frequency; $\mathrm{EE}=$ ether extract; $\mathrm{F}: \mathrm{C}=$ forage to concentrate ratio; $\mathrm{FPR}=$ fat to protein ratio; peNDF $>1.18=$ physically effective $\mathrm{NDF}$ retained on a 1.18-mm sieve; peNDF $>8=$ physically effective $\mathrm{NDF}$ retained on an 8 -mm sieve; $\overline{\mathrm{pH}}=$ daily mean ruminal $\mathrm{pH} ; \mathrm{TpH}<5.8=$ average daily time with $\mathrm{pH}<5.8 ; \Delta \mathrm{pH}=\mathrm{pH}$ range.

with a lower SEM get a higher weight in the regression analysis, resulting in a higher robustness of estimated regression coefficients.

After fitting the models, robust cluster-based estimated values for the $\mathrm{SE}$ as well as the $P$-values of the regression coefficients were estimated using the robust function from the metafor (Viechtbauer, 2019a) package. Hence, the respective study affiliation was considered for the clusters.

Furthermore, the estimated variance components were used to quantify how much of the variance not captured by the fixed effects is due to heterogeneity. This was done by calculating the generalized overall heterogeneity $\mathrm{I}^{2}$ as well as considering the betweenstudy heterogeneity $\mathrm{I}_{b s}^{2}$ according to Viechtbauer (2019b) as follows:

$$
\begin{aligned}
& \mathrm{I}^{2}(\%)=100 \times \frac{\sigma_{1}^{2}+\sigma_{2}^{2}+\sigma_{3}^{2}}{\sigma_{1}^{2}+\sigma_{2}^{2}+\sigma_{3}^{2}+\frac{k-p}{\operatorname{tr}(\mathrm{P})}} \text { and } \\
& \mathrm{I}_{b s}^{2}(\%)=100 \times \frac{\sigma_{1}^{2}}{\sigma_{1}^{2}+\sigma_{2}^{2}+\sigma_{3}^{2}+\frac{k-p}{\operatorname{tr}(\mathrm{P})}} .
\end{aligned}
$$

Here, $\sigma_{1}^{2}, \sigma_{2}^{2}$, and $\sigma_{3}^{2}$ are variance components corresponding to the model in Equation 2, $k$ is the number of treatment means, $p$ is the number of fixed effects in the model, and $\operatorname{tr}(\mathrm{P})$ is the trace of $\mathrm{P}$. Thus, $\mathrm{P}$ had to be determined using the following equation:

$$
\mathrm{P}=\mathbf{W}-\mathbf{W X}\left(\mathbf{X}^{\prime} \mathbf{W} \mathbf{X}\right)^{-1} \mathbf{X}^{\prime} \mathbf{W},
$$

where $\mathbf{W}$ is a diagonal matrix with the reciprocal sampling variances $\left(1 / v_{i}\right)$ on the diagonal and $\mathbf{X}$ is the model matrix of fixed effects. The $\mathrm{I}^{2}$ can range from 0 to $100 \%$, where $\mathrm{I}^{2}=25 \%$ corresponds to a low, $\mathrm{I}^{2}=$ $50 \%$ to a moderate, and $\mathrm{I}^{2}=75 \%$ to a high heterogeneity (Higgins et al., 2003).

Variable Selection and Multi-Model Inference. To identify the subset of variables that best quantifies the $\mathrm{pH}$ parameters, automated model selection was performed using the dredge function from the MuMIn (Barton, 2019) package in combination with the rma.mv function from the metafor (Viechtbauer, 2019a) package separately on milk and diet parameters. Since the dredge function by default is not able to handle rma.mv objects, the cooperation of these 2 packages had to be activated as described by Viechtbauer (2019c). When 
using the dredge function, sub-models are selected in the form of combinations of the fixed effects terms of the full model. This model selection can be restricted by optional rules. Besides the intercept, it was decided to limit the number of parameters to a maximum of 4 regression coefficients to achieve a reasonable and robust model. This is in accordance with Borenstein et al. (2009), who recommended one covariate per 10 studies in meta-regression. In addition to limiting the maximum number of parameters, dependency chains were used in the dredge function to ensure that only subset models containing both fat and protein were considered whenever FPR is included in a model.

In a further step, multi-model inference was used to determine the relative importance of the variables used for variable selection. This approach is based on the assumption that not only one specific model can describe the relationships of interest, but that all models found in the course of variable selection are suitable with a certain probability. This probability is determined by the Akaike weights, which are derived from the fit statistics of the entire set of models (Burnham and Anderson, 2002). As a fit statistic, the secondorder Akaike information criterion (AICc) for small samples was used as recommended by Burnham and Anderson (2002) if $n / K<40$, where $n$ is the number of observations and $\mathrm{K}$ is the number of parameters. The resulting importance of the individual variables was calculated using the importance function from the MuMIn (Barton, 2019) package. In automated variable selection, only linear regression effects were considered, given that the full model contained always the DFF as well as the DMI.

Relationship Between $\overline{p H}, \underline{T p H}<5.8$, and $\Delta p \boldsymbol{H}$. The relationship between $\overline{\mathrm{pH}}, \mathrm{TpH}<5.8$, and $\Delta \mathrm{pH}$, which are all dependent on the daily $\mathrm{pH}$ development, was also studied. In the literature, observed $\mathrm{pH}$ curves are characterized by a serrated sine-curve progression (Johnson and Sutton, 1968; Maekawa et al., 2002a). On the one hand, the daily $\mathrm{pH}$ development can be associated with the individual feed intake behavior and the DFF. Le Liboux and Peyraud (1998), for example, observed a significantly $(P<0.05)$ smaller $\Delta \mathrm{pH}$ if the $\mathrm{DFF}$ was increased from 2 to 6 . On the other hand, $\overline{\mathrm{pH}}$ and $\mathrm{TpH}<5.8$ can be associated with the dietary roughage level, and thus the energy content as well as the content of easily fermentable carbohydrates, as shown by Jiang et al. (2017).

Subsequently, the diurnal fluctuation of ruminal $\mathrm{pH}$ was abstracted as a periodic triangle wave. As visualized in Figure 3, an equation can be derived to compute the $\mathrm{TpH}<5.8$ as a function of $\overline{\mathrm{pH}}$ and $\Delta \mathrm{pH}$. Using the theorem of intersecting lines, the marked length of time (x), which corresponds to half of the $\mathrm{TpH}<5.8$, can be described as

$$
x=12 \mathrm{~h} \times\left(1-\frac{\overline{\mathrm{pH}}+0.5 \Delta \mathrm{pH}-5.8}{\Delta \mathrm{pH}}\right) .
$$

Assuming a maximum $\Delta \mathrm{pH}$ of $2 \mathrm{pH}$ units and considering the $\mathrm{pH}$ values between 5.0 and 7.0 , the $\mathrm{TpH}<5.8$ can be computed as follows:

$$
\begin{aligned}
& \mathrm{TpH}<5.8(\overline{\mathrm{pH}}, \Delta \mathrm{pH})=24 \mathrm{~h} \times\left(1-\frac{\overline{\mathrm{pH}}+0.5 \Delta \mathrm{pH}-5.8}{\Delta \mathrm{pH}}\right) \\
& \text { with } \mathrm{TpH}<5.8 \in[0 ; 24], \\
& \overline{\mathrm{pH}} \in[5+0.5 \Delta \mathrm{pH} ; 7-0.5 \Delta \mathrm{pH}] \text {, and } \\
& \Delta \mathrm{pH} \in[0.5 ; 2.0] .
\end{aligned}
$$

Based on this equation, all $\mathrm{TpH}<5.8$ depending on plausible $\overline{\mathrm{pH}}$ and $\Delta \mathrm{pH}$ combinations were calculated. For example, if the $\Delta \mathrm{pH}$ is $0.5 \mathrm{pH}$ units, $\overline{\mathrm{pH}}$ can only lie between 5.25 and 6.75 , and if $\Delta \mathrm{pH}$ is $2 \mathrm{pH}$ units, $\mathrm{pH}$ can only be 6.0. Finally, the range of predicted values was compared with actual observations.

With the exception of Figures 1, 2, and 4, all figures were programmed using the $\mathrm{R}$ ( $\mathrm{R}$ Core Team, 2018) basis functions.

\section{RESULTS AND DISCUSSION}

\section{Multiple Imputation Based on a PCA Model}

Applying the estim_ncpPCA (Husson et al., 2019) function on the raw data set, 3 principal components were determined by graphically inspecting the mean squared error of prediction depending on the number of

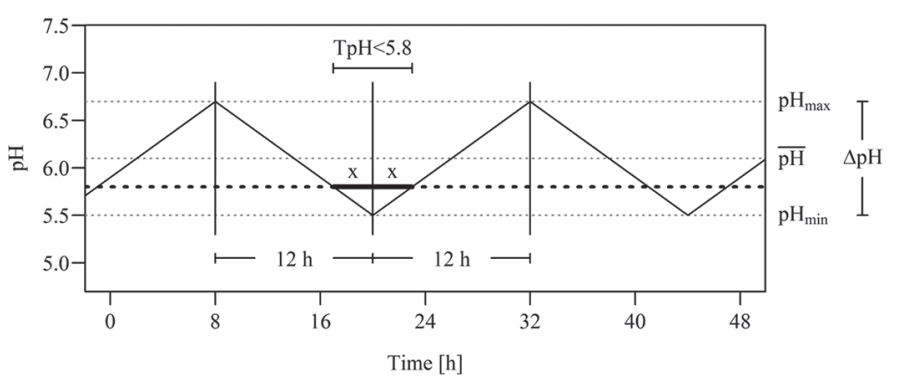

Figure 3. Schematic development of the ruminal $\mathrm{pH}$ value during the course of the day. $\overline{\mathrm{pH}}=$ daily mean ruminal $\mathrm{pH} ; \mathrm{pH}_{\min }$ and $\mathrm{pH}_{\max }$ $=$ minimum and maximum $\mathrm{pH} ; \mathrm{TpH}<5.8=$ average daily time with $\mathrm{pH}<5.8 ; \Delta \mathrm{pH}=\mathrm{pH}$ range. 
principal components used. A higher number of principal components did not lead to a substantial reduction of the residual mean squared error of prediction. Afterward, the variable factor map shown in Figure 4 was created to assess the quality of the imputation of missing values. This variable factor map is based on the averaged data set, which resulted from 100 imputations created with a bootstrap method. Displayed as arrows, all 20 predictors as well as the $3 \mathrm{pH}$ parameters are shown in the space of the first 2 principal components, which explain together $53.13 \%$ of the observed total variance in the data set. The coordinates of the arrowheads show the loadings and correspond to the correlation of the individual variables with the respective principal component. Additionally, the loadings of the variables from the 100 imputed data sets are projected in the same space to assess the imputing quality. The point clouds are only slightly scattered around the arrowheads, which indicates that the imputing procedure is appropriate for the available data. Only the variables with the highest proportion of missing values show an increased dispersion and indicate an increased uncertainty of prediction. Especially MUN exhibits by far the highest uncertainty. Moreover, the distributions of the variables before and after imputing were compared graphically and with a 2-sample Kolmogorov-Smirnov test (see Supplemental Figure S1, https://doi.org/10 $.3168 /$ jds.2019-16802). The null hypothesis assuming

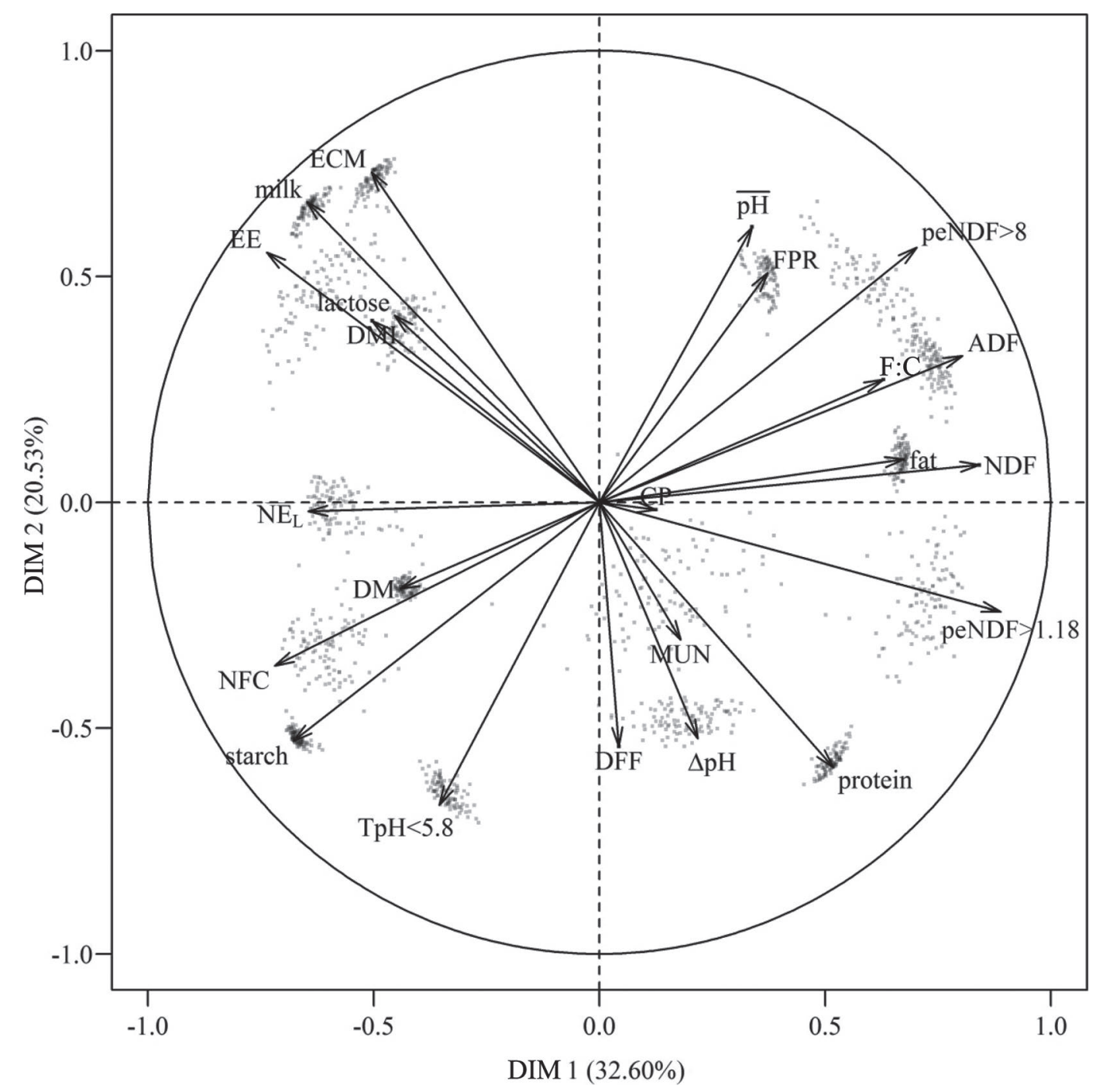

Figure 4. Variable factor map (Husson et al., 2019) using the first 2 principal components based on the averaged multiple imputed data set. In addition to the loadings from the variables of the averaged data set (arrows), the loadings from the 100 imputed data sets are projected in the same space (points). DFF = daily feeding frequency; $\mathrm{EE}=$ ether extract; $\mathrm{F}: \mathrm{C}=$ forage to concentrate ratio; $\mathrm{FPR}=$ fat to protein ratio; peNDF $>1.18=$ physically effective NDF retained on a $1.18-\mathrm{mm}$ sieve; peNDF $>8=$ physically effective NDF retained on an 8 -mm sieve; $\overrightarrow{\mathrm{pH}}$ $=$ daily mean ruminal $\mathrm{pH} ; \mathrm{TpH}<5.8=$ average daily time with $\mathrm{pH}<5.8 ; \Delta \mathrm{pH}=\mathrm{pH}$ range. 
that both samples originate from the same continuous distribution could not be rejected for any variable $(\alpha=$ 0.05). This confirmed the applicability and usefulness of the applied imputation procedure.

Within the framework of this multivariate analysis method, it was not only possible to handle the problem of missing values, but also to derive the associations between the variables from the variable factor map. In general, positively correlated variables appear grouped and negatively correlated variables are positioned on the opposite side of the center. As already described by Zebeli et al. (2008), the $\mathrm{pH}$ parameters $\mathrm{TpH}<5.8$ and $\overline{\mathrm{pH}}$ are highly negatively correlated. As to be expected, this is also confirmed here by the variable factor map shown in Figure 4, since the $2 \mathrm{pH}$ parameters are positioned almost exactly opposite to each other. Furthermore, it can be seen that especially the fiber-associated variables peNDF $>1.18$, peNDF $>8, \mathrm{ADF}, \mathrm{NDF}$, and the forage to roughage ratio are relatively close to each other. On the opposite side are parameters of the diet that are primarily associated with the energy content, including starch, NFC, and $\mathrm{NE}_{\mathrm{L}}$. The $\mathrm{DM}$ is also positioned opposite to the fiber-associated variables, since a higher proportion of concentrate increases the DM content of the diet, ceteris paribus.

The interpretation of variables with a shorter distance between the center and the arrowhead has to be carried out with caution. Even though it seems that $\mathrm{DFF}$ and $\mathrm{pH}$ range cluster together, the variable factor map for the 1st and 3rd principal component (plot not shown) revealed that they are positioned opposite to each other. The same is true for $\overline{\mathrm{pH}}$ and FPR.

Since no potential predictors are present in the immediate neighborhood of the $\mathrm{pH}$ parameters, it was concluded that none of them was highly associated with $\mathrm{pH}$ parameters. Thus, only several variables together are able to explain the observed variance of $\overline{\mathrm{pH}}$ and $\mathrm{TpH}<5.8$. The multivariate approach via PCA was a pre-analysis to give an overview of the relationships between all considered variables. A limitation of this method is that the hierarchical data structure is not considered.

\section{Multi-Level Meta-Regression for All Potential Predictors}

In the next step, each $\mathrm{pH}$ parameter was analyzed in a multi-level meta-regression model (Equation 2), considering only one predictor at a time to identify those that have the strongest association. This analysis was performed on the raw data set with missing values as well as for the imputed data set. To allow for comparability, all predictors were z-transformed so that the es- timated regression coefficients $\left(\hat{b}_{1}\right)$ of the slope are dimensionless. The results of this analysis are shown in Figure 5, where all $\hat{b}_{1}$ are represented separately for all $3 \mathrm{pH}$ parameters by bar charts. The predictors were sorted within the variable groups of milk and diet in descending order of the $P$-value of the $\hat{b}_{1}$ based on the raw data set. The error bars correspond to 1.96 times the robust standard error of the estimated value and thus show the robust $95 \%$ confidence interval. At first glance, it can be seen that the results tend to be very consistent for both the raw and the imputed data set. The main exceptions are the estimated regression coefficients of MUN for all $3 \mathrm{pH}$ parameters and the estimates of $\mathrm{EE}$ for $\overline{\mathrm{pH}}$ and $\mathrm{TpH}<5.8$. With MUN, a greater or even opposite effect is estimated on the basis of the imputed data set. With EE, on the other hand, the effect present in the raw data lost significance by the imputation. Based on the fact that the remaining estimates are very similar for both data sets, further support is gained for the supposition that the imputation of the missing observations to this data set is justifiable.

As expected, all $\hat{b}_{1}$ regression coefficients for $\overline{\mathrm{pH}}$ and $\mathrm{TpH}<5.8$ are negatively correlated, because both $\mathrm{pH}$ parameters are strongly negatively correlated as discussed before. It can be seen that the sign of the estimated values for $\Delta \mathrm{pH}$ corresponds to those for $\mathrm{TpH}<$ 5.8 and is therefore negatively correlated with those of $\overline{\mathrm{pH}}$. From the group of milk variables, FPR, protein, and fat have a significant association $(P<0.001)$ on all $3 \mathrm{pH}$ parameters with FPR having the lowest $P$-value. The positive sign of fat for the $\overline{\mathrm{pH}}$ is consistent with the general assumption that low ruminal $\mathrm{pH}$ values can also contribute to a milk fat depression as described by Nocek (1997) and Kleen et al. (2003). For example, Danscher et al. (2015) were able to show that significantly $(P=0.01)$ lower $\mathrm{pH}$ values tend to be accompanied by lower milk fat values $(P=0.06)$ in SARAchallenged heifers. The authors did not find any significant differences in milk protein between the 2 groups. However, the results of such studies are not consistent in the literature. For example, Krause and Oetzel (2005) could not detect a milk fat depression on the basis of SARA-challenged lactating cows.

The positive association with FPR is consistent with the fat content and supports suggestions that this measure has potential as an indicator of SARA in dairy cows. However, it is interesting to note that although primary milk fat depression is postulated for SARA, the $\overline{\mathrm{pH}}$ and protein content of milk have an obviously negative association. In this respect, Rook and Balch (1961) showed that an intraruminal propionate infusion resulted in a decrease of the fat and an increase of the 

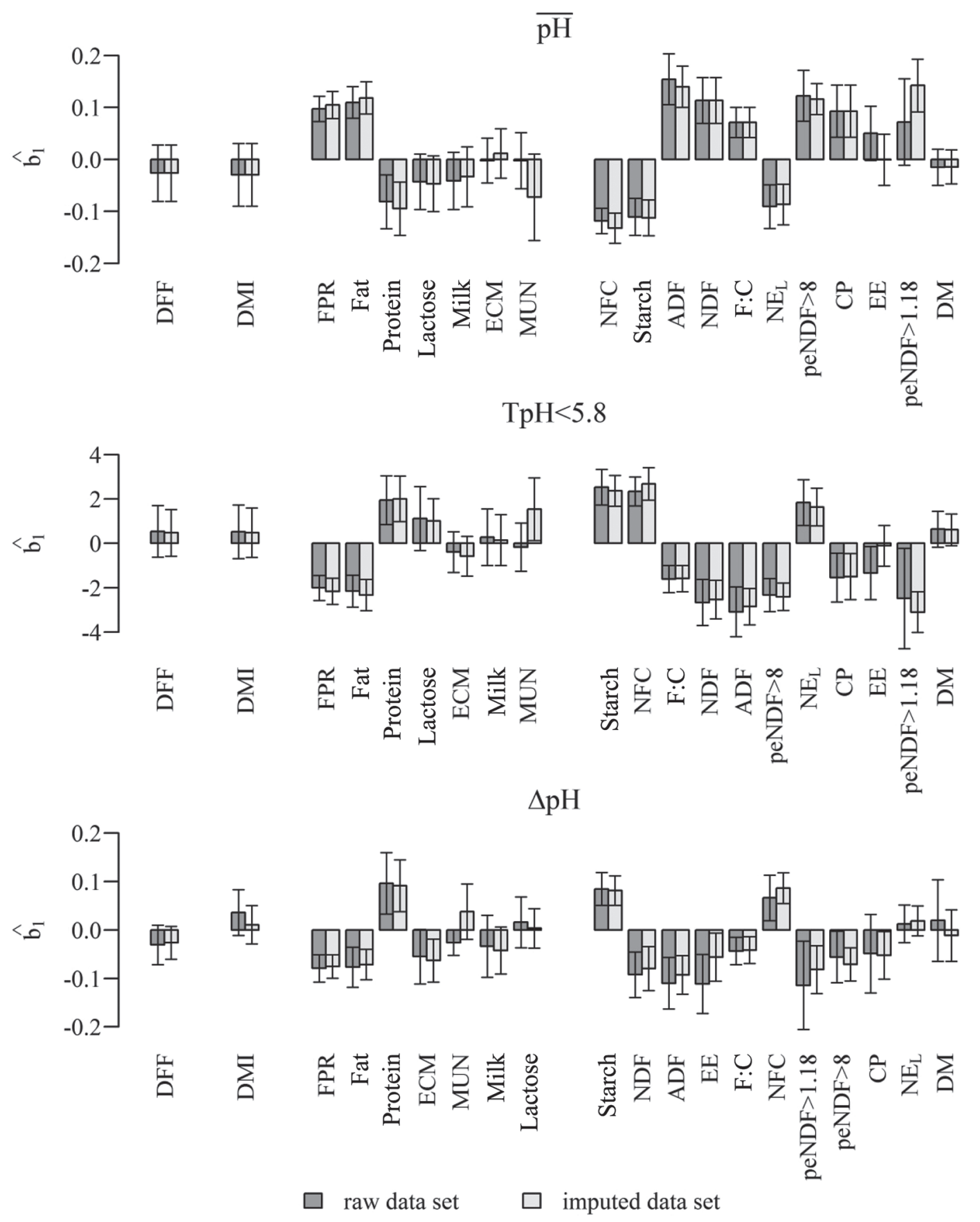

Figure 5. Results of regression analysis in which all $3 \mathrm{pH}$ parameters were analyzed individually with each potential predictor in a multilevel meta-regression model. This analysis was performed with both the raw (dark gray) and the imputed (light gray) data set. For better comparability, all predictors were z-transformed previously. The height of the bars represents the estimated regression coefficients $\left(\hat{b}_{1}\right)$. The error bars correspond to 1.96 times the robust $\mathrm{SE}$ of $\hat{\mathrm{b}}_{1}$. DFF = daily feeding frequency; $\mathrm{EE}=$ ether extract; $\mathrm{F}: \mathrm{C}=$ forage to concentrate ratio; $\mathrm{FPR}=$ fat to protein ratio; peNDF $>1.18=$ physically effective NDF retained on a 1.18 -mm sieve; peNDF $>8=$ physically effective NDF retained on an $8-\mathrm{mm}$ sieve; $\overline{\mathrm{pH}}=$ daily mean ruminal $\mathrm{pH} ; \mathrm{TpH}<5.8=$ average daily time with $\mathrm{pH}<5.8 ; \Delta \mathrm{pH}=\mathrm{pH}$ range.

protein content of the milk and thus a decreasing FPR. Assuming that a lower $\overline{\mathrm{pH}}$ can be accompanied with a higher ruminal propionate ratio as described by Russell (1998), the negative sign of the regression coefficient of protein and the positive sign of the FPR is consistent with the aforementioned association (Rook and Balch, 1961). All other milk-associated parameters showed no significant effect as a single predictor in a multi-level 
mixed effect regression model. At this point it has to be noted that the models with FPR as single predictor generally have to be interpreted carefully. As discussed by Kronmal (1993), the use of ratios as an independent variable in a regression model without the 2 independent variables used to calculate the ratio is critical.

In addition to the meta-regression analysis, the $\mathrm{pH}$ parameters and potential predictors were examined graphically using scatterplots. Figure 6 shows 3 predictors for each of the $3 \mathrm{pH}$ parameters that are characterized by the smallest $P$-value (see Supplemental Figures S2, S3, and S4; https://doi.org/10.3168/jds .2019-16802). Imputed values, either the predictor, the $\mathrm{pH}$ parameter, or both, are depicted by gray triangles, whereas black dots represent observed values. To represent the hierarchical data structure, observations from the same study were linked by lines or, in the case of imputed values, by dashed lines. Moreover, the regression lines, which are based on the raw and on the imputed data set, were added. In all cases, the regression line is based only on the fixed effect part of the model and consists of an intercept and a slope. Obviously, there is an immense heterogeneity among the treatments and across individual studies. It can be seen that single predictors are only able to explain a small part of the observed variance. In each plot, both regression lines are nearly congruent, even though in the case of NFC $49.1 \%$ of the observations were imputed.

\section{Variable Selection and Multi-Model Inference}

In total, 6 models (M1 to $\mathbf{M 6}$ ) were generated with the automated variable selection on the imputed data set, which are shown in Table 3. The uncertainty for the imputed MUN values was by far the lowest and the previous regression analysis led to deviating results. Therefore MUN was not considered in this part of the analysis.

For all $3 \mathrm{pH}$ parameters, the selected models based on the variable selection with diet parameters (M2, M4, and M6) demonstrated a better model accuracy (AICc) compared with the models containing milk parameters (M1, M3, and M5). For the 2 parameters $\mathrm{pH}$ and $\mathrm{TpH}$ $<5.8$, similar variables were selected. If only milk variables were considered, DFF, fat, protein, and lactose were selected for both parameters. Taking into account diet variables, DM, EE, as well as peNDF $>8$ were selected for $\overrightarrow{\mathrm{pH}}$ and $\mathrm{TpH}<5.8$, whereby NFC was additionally selected for $\overline{\mathrm{pH}}$ and starch for $\mathrm{TpH}<5.8$. The variables chosen for $\Delta \mathrm{pH}$ corresponded approximately to those selected for $\overline{\mathrm{pH}}$ and $\mathrm{TpH}<5$.8. Instead of lactose, ECM was selected in the variable selection with milk parameters, and DFF instead of DM with respect to diet parameters.
It was surprising that if diet variables were available, EE was selected in all 3 models. The EE content of the diet is generally not linked to a low ruminal $\mathrm{pH}$, although indications of relationships are reported in the literature. For example, Ikwuegbu and Sutton (1982) investigated sheep and were able to show that the addition of linseed oil led to a change in the mean concentration of acetate, propionate, and n-butyrate as well as to reduction of digestibility of energy, OM, and ADF. Although the authors could not determine any significant effect of the linseed oil on the $\mathrm{pH}$, the altered VFA profile shows an effect of dietary fat on the ruminal fermentation process. It is well known that dietary fat and its composition can affect both milk composition and digestibility of the fiber content. Harvatine and Allen (2006a), for example, were able to demonstrate that the addition of PUFA led to a significant reduction in milk fat, energy intake, and milk energy yield. In addition, a change in the fatty acid pattern was observed, whereby a higher PUFA content led to a lower proportion of short- and medium-chain fatty acids. Furthermore, Harvatine and Allen (2006c) demonstrated that the saturation of supplemented fatty acids affected the digestibility of NDF. Thereby, SFA caused a decrease and UFA an increase of ruminal NDF digestibility. The authors also found that the total-tract digestibility did not differ due to compensatory postruminal digestion. As Harvatine and Allen (2006a) also mentioned, the dietary fat and thus EE can be classified as a fermentation modifier. Interestingly, no effect of fatty acid supplementation on $\overline{\mathrm{pH}}$ was observed in the same experiment. Nevertheless, the authors could determine an increased $\Delta \mathrm{pH}$ and $\mathrm{pH}$ variance due to supplementation of SFA. This is remarkable because $\mathrm{EE}$ also showed the most significant effect on $\Delta \mathrm{pH}$ compared with the effect on $\overline{\mathrm{pH}}$ and $\mathrm{TpH}<5.8$ in our analysis. When considered as single predictor in the model based on the raw data set (see Figure 5), EE showed a significant effect on $\mathrm{TpH}<5.8(P<0.05)$ and $\Delta \mathrm{pH}(P<0.01)$ as well as a trend for $\overline{\mathrm{pH}}(P<$ 0.1 ). The same trend was also observed in the multimodel inference regarding the relative importance of EE (see Figure 7). This insight supports the decision to exclude studies from this meta-analysis that used diets supplemented with fatty acids to reduce the possibility of additional bias.

Fat and protein content were present in all milk production models, although the FPR showed the most significant association when considered alone in a model. This is probably due to the dependency chains, but also means that fat and protein as 2 independent variables are mainly associated with the $\mathrm{pH}$ parameters and that the additional consideration of the FPR does not lead to any further model improvement. 

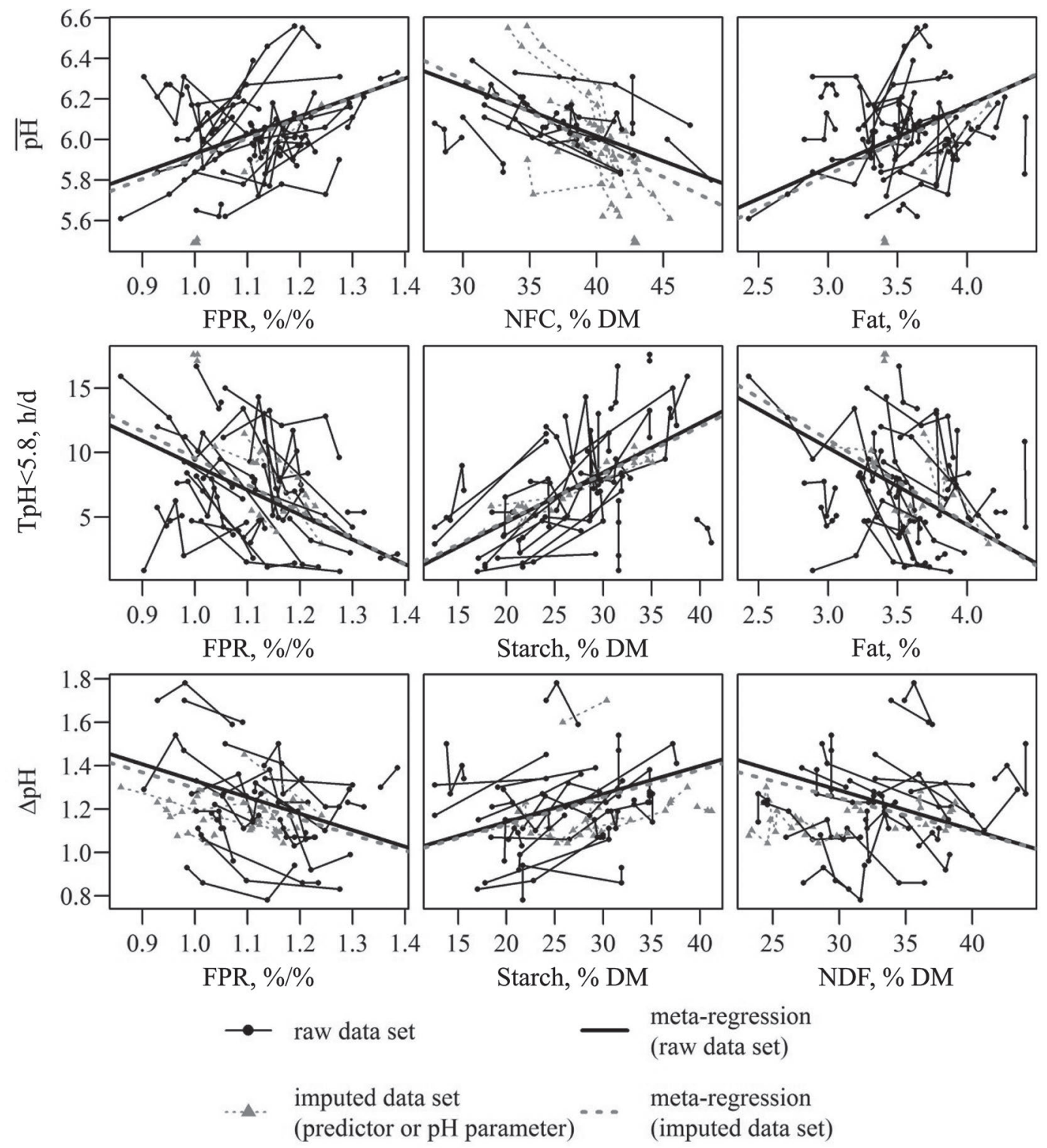

Figure 6. Scatterplots for the pH parameters as well as the 3 predictors with highest significance. The actual observed data (black) and the imputed data (gray) are shown. In the latter case the $\mathrm{pH}$ parameter, the predictor, or both were imputed. Observations from the same study were linked by a line or, in the case of imputed data, by gray dashed lines. Further, the regression lines based on the fixed effect part of a multilevel meta-regression model are drawn. The black bold line shows the regression line estimated using the raw data set, and the gray bold dashed line shows the regression line estimated using the imputed data set. $\mathrm{FPR}=$ fat to protein ratio; $\overline{\mathrm{pH}}=$ daily mean $\mathrm{ruminal} \mathrm{pH} ; \mathrm{TpH}<5.8=$ average daily time with $\mathrm{pH}<5.8 ; \Delta \mathrm{pH}=\mathrm{pH}$ range.

If only milk variables were available, lactose was selected for $\overline{\mathrm{pH}}$ and $\mathrm{TpH}<5.8$ in $\mathrm{M} 1$ and $\mathrm{M} 3$. With regard to lactose, only Enemark et al. (2002) have reported an increased lactose content caused by SARA as a consequence of increased ruminant propionate formation and thus an associated elevated blood sugar level. The lactose content is promising as a potential predictor because it is the most constant ingredient of the milk (NRC, 2001) and is therefore only marginally influenced by the lactation stage, whereas the protein and fat content of the milk are affected in the course of lactation (Stanton et al., 1992).

From the estimates from $\mathrm{I}^{2}$ and $\mathrm{I}_{b s}^{2}$ for all models, it can be deduced that the present data set shows a very high overall heterogeneity among the individual treatments, which is mainly caused by between-study heterogeneity. It can be assumed that a certain degree of heterogeneity is due to insufficient modeling of the predictors. Based on this meta-analysis, the concrete sources of heterogeneity cannot be identified and fur- 
ther research is required. In general, a large inter-farm variability for $\mathrm{pH}$ measurements in the forestomach system is reported in the literature. For example, Denwood et al. (2018) were able to demonstrate that both the range of reticular measured $\mathrm{pH}$ and the $\mathrm{pH}$ progressions varied among 13 different farms, which could be traced back to different rations and management influences such as milking frequency.

As already derived from the results of the PCA, $\overline{\mathrm{pH}}$, $\mathrm{TpH}<5.8$, and $\Delta \mathrm{pH}$ are not easily predictable traits, but complex parameters. Based on the results of Golder et al. (2018), it can be assumed that the pH param-

Table 3. Results of variable selection for daily mean ruminal $\mathrm{pH}$, the average daily time with $\mathrm{pH}<5.8$, and the $\mathrm{pH}$ range using the imputed data set $(k=32 \text { studies, } \mathrm{n}=112 \text { treatment means })^{1}$

\begin{tabular}{|c|c|c|c|c|}
\hline \multirow[b]{2}{*}{ Item } & \multicolumn{2}{|c|}{ M1 (milk) } & \multicolumn{2}{|c|}{ M2 (diet) } \\
\hline & $\hat{\mathrm{b}}$ & $\mathrm{SE}$ & $\hat{\mathrm{b}}$ & $\mathrm{SE}$ \\
\hline \multicolumn{5}{|l|}{$\overline{\mathrm{pH}}$} \\
\hline Intercept, pH & 8.8849 & $0.8435^{* * *}$ & 5.9699 & $0.2354^{* * *}$ \\
\hline DFF, $1 / \mathrm{d}$ & -0.0571 & $0.0277^{*}$ & & \\
\hline Fat, $\%$ & 0.2861 & $0.0372^{* * *}$ & & \\
\hline Protein, \% & -0.5169 & $0.1048^{* * *}$ & & \\
\hline Lactose, \% & -0.4528 & $0.1431^{* *}$ & & \\
\hline $\mathrm{DM}, \%$ of $\mathrm{DM}$ & & & 0.0081 & $0.0019^{* * *}$ \\
\hline $\mathrm{EE}, \%$ of DM & & & 0.0457 & 0.0225 \\
\hline peNDF $>8, \%$ of DM & & & 0.0173 & $0.0039^{* * *}$ \\
\hline $\mathrm{NFC}, \%$ of $\mathrm{DM}$ & & & -0.0210 & $0.0037^{* * *}$ \\
\hline $\mathrm{AICc}$ & -134.33 & & -164.11 & \\
\hline $\mathrm{I}^{2}, \%$ & 88.0 & & 82.6 & \\
\hline \multirow[t]{2}{*}{$\mathrm{I}_{b s}^{2}, \%$} & 45.8 & & 43.3 & \\
\hline & \multicolumn{2}{|c|}{ M3 (milk) } & \multicolumn{2}{|c|}{ M4 (diet) } \\
\hline \multicolumn{5}{|l|}{$\mathrm{TpH}<5.8$} \\
\hline Intercept, $\mathrm{h} / \mathrm{d}$ & -57.8745 & $17.2019^{* *}$ & 20.9985 & $4.4234^{* * *}$ \\
\hline DFF, $1 / d$ & 0.9958 & $0.4664^{*}$ & & \\
\hline Fat, $\%$ & -5.5599 & $0.9261 * * *$ & & \\
\hline Protein, $\%$ & 11.4912 & $2.0459^{* * *}$ & & \\
\hline Lactose, $\%$ & 9.8551 & $2.8286^{* *}$ & & \\
\hline $\mathrm{DM}, \%$ of DM & & & -0.1398 & $0.0413^{* *}$ \\
\hline $\mathrm{EE}, \%$ of DM & & & -0.9641 & $0.4177^{*}$ \\
\hline Starch, \% of DM & & & 0.1763 & $0.0586^{* *}$ \\
\hline peNDF $>8, \%$ of DM & & & -0.4957 & $0.0972^{* * *}$ \\
\hline $\mathrm{AICc}$ & 532.23 & & 514.96 & \\
\hline $\mathrm{I}^{2}, \%$ & 87.0 & & 82.0 & \\
\hline \multirow[t]{2}{*}{$\mathrm{I}_{b s}^{2}, \%$} & 55.0 & & 54.0 & \\
\hline & \multicolumn{2}{|c|}{ M5 (milk) } & \multicolumn{2}{|c|}{ M6 (diet) } \\
\hline \multicolumn{5}{|l|}{$\Delta \mathrm{pH}$} \\
\hline Intercept, pH & 0.6874 & 0.4286 & 1.8482 & $0.2709 * * *$ \\
\hline $\mathrm{DFF}, 1 / \mathrm{d}$ & -0.0592 & 0.0449 & -0.1061 & $0.0495^{*}$ \\
\hline ECM, kg/d & -0.0075 & 0.0038 & & \\
\hline Fat, $\%$ & -0.1663 & $0.0415^{* * *}$ & & \\
\hline Protein, $\%$ & 0.4585 & $0.1167^{* * *}$ & & \\
\hline $\mathrm{EE}, \%$ of DM & & & -0.1382 & $0.0346^{* * *}$ \\
\hline Starch, \% of DM & & & 0.0088 & $0.0032^{*}$ \\
\hline peNDF $>8, \%$ of $\mathrm{DM}$ & & & -0.0133 & $0.0048^{*}$ \\
\hline $\mathrm{AICc}$ & -164.72 & & -177.78 & \\
\hline $\mathrm{I}^{2}, \%$ & 77.0 & & 76.4 & \\
\hline $\mathrm{I}_{b s}^{2}, \%$ & 60.4 & & 47.7 & \\
\hline
\end{tabular}

${ }^{1} \mathrm{M} 1$ to $\mathrm{M} 6=$ models 1 to 6 , respectively: $\mathrm{AICc}=$ second order Akaike information criterion for small sample sizes; $\hat{b}=$ estimate; $\mathrm{DFF}=$ daily feeding frequency; $\mathrm{EE}=$ ether extract; $\mathrm{I}^{2}=$ test statistic to quantify the overall heterogeneity; $\mathrm{I}_{b s}^{2}=$ test statistic to quantify the between-study heterogeneity; peNDF $>8=$ physically effective $\mathrm{NDF}$ retained on an $8-\mathrm{mm}$ sieve; $\overline{\mathrm{pH}}=$ daily mean ruminal $\mathrm{pH}$; $\mathrm{TpH}<5.8=$ average daily time with $\mathrm{pH}<5.8 ; \Delta \mathrm{pH}=\mathrm{pH}$ range.

$* * * P<0.001,{ }^{* *} P<0.01$, and $* P<0.05$. 
eters depend on the entire metabolism of the cow as well as the interactions between the cow, ruminal microbiome, and diet. Because this relationship is not easy to grasp with a single model, a multi-model inference was applied and the relative importance of the individual parameters within each of the 6 model selection procedures was determined. In Figure 7, the relative importance varying from 0 to 1 of each variable is represented by the diameter of the circle, where a small circle displays a low and a big circle a high relative importance. It can be seen, that the DM, EE, NFC, and peNDF $>8$ content carry the largest relative importance among the diet parameters. With regard to the milk parameters, especially protein, fat, and lactose show the highest relative importance. In comparison, Zebeli et al. (2008) identified the squared term of peNDF $>1.18$, ruminally degradable starch from grain, and the DMI, applying a backward elimination technique to predict the $\mathrm{pH}$ in a multiple regression model.

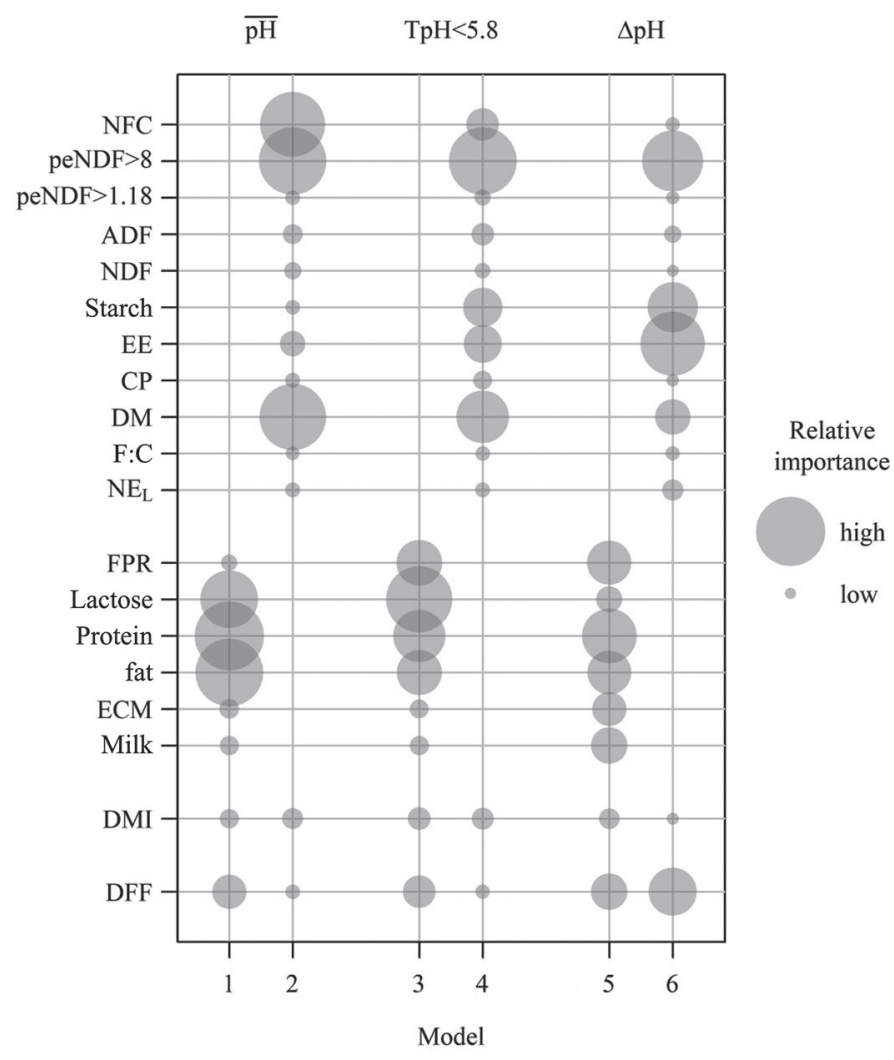

Figure 7. Visualization of the estimated relative importance of each variable derived from the multi-model inference for all 6 models. The diameter of the gray circles represents the estimated relative importance of each variable within the model. $\mathrm{DFF}=$ daily feeding frequency; $\mathrm{EE}=$ ether extract; $\mathrm{F}: \mathrm{C}=$ forage to concentrate ratio; $\mathrm{FPR}$ $=$ fat to protein ratio; peNDF $>1.18=$ physically effective NDF retained on a 1.18-mm sieve; peNDF $>8=$ physically effective NDF retained on an $8-\mathrm{mm}$ sieve; $\mathrm{pH}=$ daily mean ruminal $\mathrm{pH} ; \mathrm{TpH}<5.8$ $=$ average daily time with $\mathrm{pH}<5.8 ; \Delta \mathrm{pH}=\mathrm{pH}$ range.
In another study, a comparable model using the peNDF $>8$, the starch content of the diet and DMI were selected to predict $\mathrm{pH}$ (Zebeli et al., 2010). Because the starch and NFC content of the diet are highly positively correlated, this is consistent with our results. What differs, however, is that the DMI was not selected in any of the present models in the variable selection and appeared to be only of relatively minor importance.

The modeling of $\Delta \mathrm{pH}$ showed that DFF also had a significant effect. The signs of the partial regression coefficients of the models M5 and M6 show that a more frequent supply of feed is accompanied by a lower $\mathrm{pH}$ range. This is in line with the results of Le Liboux and Peyraud (1998) and indicates that the entire management contributes to the $\mathrm{pH}$ development.

\section{Relationship Between $\mathrm{TpH}$ and $\overline{\mathrm{pH}}$}

Based on Equation 6, all possible $\mathrm{TpH}<5.8$ as a function of plausible $\overrightarrow{\mathrm{pH}}$ and $\Delta \mathrm{pH}$ combinations were calculated and are shown in Figure 8. The predicted range of $\mathrm{TpH}<5.8$ for a certain $\overline{\mathrm{pH}}$ is illustrated by a grayscale gradient. Except for $\overline{\mathrm{pH}}$, there is a range of conceivable $\mathrm{TpH}<5.8$ for all other plausible $\overline{\mathrm{pH}}$. The reason for that is that if $\overline{\mathrm{pH}}=5.8$ the content of the brackets in Equation 6 is cut short by $\Delta \mathrm{pH}$ and therefore only $\mathrm{TpH}<5.8=12 \mathrm{~h}$ is possible. For the remaining value range of $\overline{\mathrm{pH}}$, a variation in $\mathrm{TpH}<5.8$ exists depending on $\Delta \mathrm{pH}$. To validate this theory, the observed data from all studies were added to the plot. Although the assumptions are highly simplified in our theoretical relationship between $\mathrm{TpH}<5.8$ and $\mathrm{pH}$, approximately $90 \%$ of the observed data are in the predicted range. This agreement confirms the association described in Equation 6. This approach differs from modeling with a broken line model, as conducted by Zebeli et al. (2008).

\section{CONCLUSIONS}

In many animal feeding experiments sample size is restricted, particularly if surgical procedures, as in the case of ruminal fistulated cows, are used. The application of meta-analytical methods proved to be a powerful tool for obtaining a comprehensive overview of physiological relationships between diet, rumen, and milk properties. In the meta-regression analysis, the fat, protein, and FPR could be identified and confirmed as indicators for rumen $\mathrm{pH}$ parameters and, thus, in the broader sense, also for SARA. Interestingly, also the lactose content of the milk was selected in the automated variable selection and indicated the ability to improve the predictability for ruminal $\mathrm{pH}$ parameters. With regard to diet-specific variables, significant ef- 


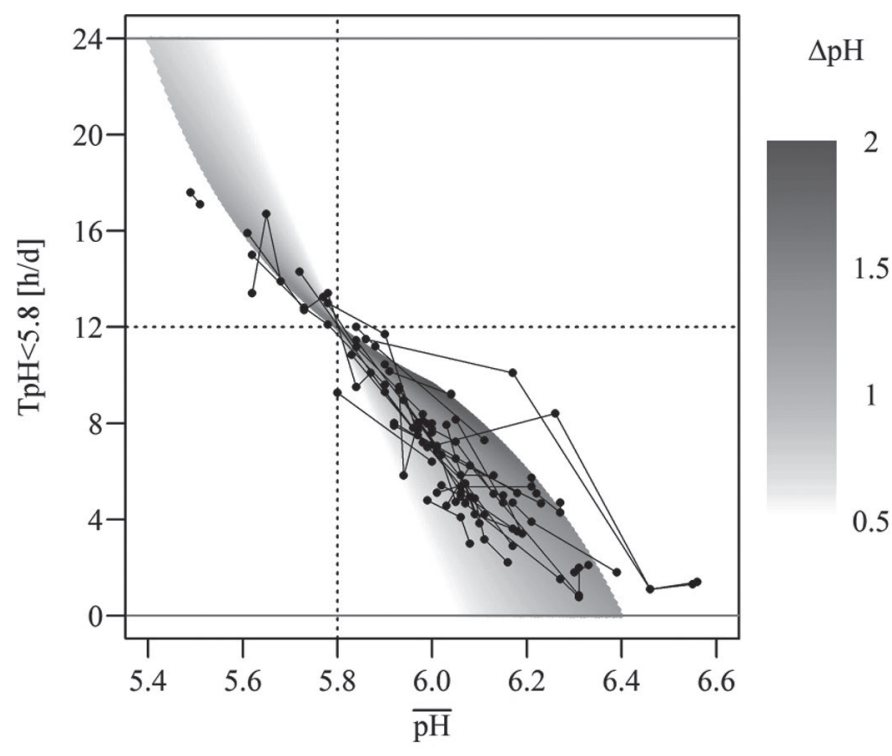

Figure 8. Relationship between average daily time with $\mathrm{pH}<5.8$ $(\mathrm{TpH}<5.8)$, daily mean ruminal $\mathrm{pH}(\overline{\mathrm{pH}})$, and $\mathrm{pH}$ range $(\Delta \mathrm{pH})$. All observed treatment means within one study are linked by a line. The gray scale gradient in the background represents the theoretical values for $\mathrm{TpH}<5.8$ depending on a given $\Delta \mathrm{pH}$ and $\overline{\mathrm{pH}}$ predicted by Equation 6.

fects for peNDF $>8, \mathrm{ADF}, \mathrm{NDF}, \mathrm{NFC}$, starch, as well as the $\mathrm{F}: \mathrm{C}$, were identified. We can confirm that milk constituents are associated with the ruminant $\mathrm{pH}$ value and that these can be used as indicators for monitoring purposes. In the future it should be clarified to what extent further information, (e.g., on the fine milk composition, particularly the fatty acid pattern of the milk) can contribute to explaining the association between ruminal $\mathrm{pH}$ and the milk to find better indicators for SARA.

\section{ACKNOWLEDGMENTS}

This work was done within the project "Evaluation of Animal Welfare in Dairy Farming - Indicators for the Metabolism and Feeding" (IndiKuh, funding code: 2817905815) and was supported by the German Federal Ministry for Food and Agriculture (BMEL) according to a decision of the German Federal Parliament. The project sponsorship was conducted by the Federal Office for Agriculture and Food (BLE) in the course of the program for promotion of innovations.

\section{REFERENCES}

AlZahal, O., E. Kebreab, J. France, M. Froetschel, and B. W. McBride. 2008. Ruminal temperature may aid in the detection of subacute ruminal acidosis. J. Dairy Sci. 91:202-207. https://doi .org/10.3168/jds.2007-0535.
AlZahal, O., M. M. Or-Rashid, S. L. Greenwood, M. S. Douglas, and B. W. McBride. 2009. The effect of dietary fiber level on milk fat concentration and fatty acid profile of cows fed diets containing low levels of polyunsaturated fatty acids. J. Dairy Sci. 92:11081116. https://doi.org/10.3168/jds.2008-1472.

Barton, K. 2019. MuMIn: Multi-Model Inference, Version 1.43 .6 1-75.

Bauman, D. E., and J. M. Griinari. 2003. Nutritional regulation of milk fat synthesis. Annu. Rev. Nutr. 23:203-227. https://doi.org/ 10.1146/annurev.nutr.23.011702.073408.

Beauchemin, K. A., and W. Z. Yang. 2005. Effects of physically effective fiber on intake, chewing activity, and ruminal acidosis for dairy cows fed diets based on corn silage. J. Dairy Sci. 88:21172129. https://doi.org/10.3168/jds.s0022-0302(06)72086-0.

Beauchemin, K. A., W. Z. Yang, and L. M. Rode. 2003. Effects of particle size of alfalfa-based dairy cow diets on chewing activity, ruminal fermentation, and milk production. J. Dairy Sci. 86:630-643. https://doi.org/10.3168/jds.S0022-0302(03)73641-8.

Bhandari, S. K., S. Li, K. H. Ominski, K. M. Wittenberg, and J. C. Plaizier. 2008. Effects of the chop lengths of alfalfa silage and oat silage on feed intake, milk production, feeding behavior, and rumen fermentation of dairy cows. J. Dairy Sci. 91:1942-1958. https: //doi.org/10.3168/jds.2007-0358.

Borenstein, M., L. V. Hedges, J. P. T. Giggins, and H. R. Rothstein. 2009. Introduction to Meta-Analysis. Wiley, Chichester, UK.

Bramley, E., I. J. Lean, W. J. Fulkerson, M. A. Stevenson, A. R. Rabiee, and N. D. Costa. 2008. The definition of acidosis in dairy herds predominantly fed on pasture and concentrates. J. Dairy Sci 91:308-321. https://doi.org/10.3168/jds.2006-601.

Burnham, K. P., and D. R. Anderson. 2002. Model Selection and Multimodel Inference: A Practical Information-Theoretic Approach. Springer, New York, NY.

Buttchereit, N., E. Stamer, W. Junge, and G. Thaller. 2010. Evaluation of five lactation curve models fitted for fat:protein ratio of milk and daily energy balance. J. Dairy Sci. 93:1702-1712. https:/ /doi.org/10.3168/jds.2009-2198.

Chibisa, G. E., P. Gorka, G. B. Penner, R. Berthiaume, and T. Mutsvangwa. 2015. Effects of partial replacement of dietary starch from barley or corn with lactose on ruminal function, short-chain fatty acid absorption, nitrogen utilization, and production performance of dairy cows. J. Dairy Sci. 98:2627-2640. https://doi.org/ $10.3168 /$ jds.2014-8827.

Dann, H. M., S. M. Fredin, K. W. Cotanch, R. J. Grant, C. Kokko, P. Ji, and K. Fujita. 2015. Effects of corn-based reduced-starch diets using alternative carbohydrate sources on performance of lactating Holstein cows. J. Dairy Sci. 98:4041-4054. https://doi.org/10 $.3168 /$ jds.2014-9078.

Dann, H. M., H. A. Tucker, K. W. Cotanch, P. D. Krawczel, C. S. Mooney, R. J. Grant, and T. Eguchi. 2014. Evaluation of lower-starch diets for lactating Holstein dairy cows. J. Dairy Sci. 97:7151-7161. https://doi.org/10.3168/jds.2014-8341.

Danscher, A. M., S. Li, P. H. Andersen, E. Khafipour, N. B. Kristensen, and J. C. Plaizier. 2015. Indicators of induced subacute ruminal acidosis (SARA) in Danish Holstein cows. Acta Vet. Scand. 57:39. https://doi.org/10.1186/s13028-015-0128-9.

Denwood, M. J., J. L. Kleen, D. B. Jensen, and N. N. Jonsson. 2018. Describing temporal variation in reticuloruminal $\mathrm{pH}$ using continuous monitoring data. J. Dairy Sci. 101:233-245. https://doi .org/10.3168/jds.2017-12828.

Enemark, J. M. D. 2008. The monitoring, prevention and treatment of sub-acute ruminal acidosis (SARA): A review. Vet. J. 176:32-43. https://doi.org/10.1016/j.tvjl.2007.12.021.

Enemark, J. M. D., R. J. Jørgensen, and P. St. Enemark. 2002. Rumen acidosis with special emphasis on diagnostic aspects of subclinical rumen acidosis: A review. Vet. IR Zootech. 20:16-29.

Farmer, E. R., H. A. Tucker, H. M. Dann, K. W. Cotanch, C. S. Mooney, A. L. Lock, K. Yagi, and R. J. Grant. 2014. Effect of reducing dietary forage in lower starch diets on performance, ruminal characteristics, and nutrient digestibility in lactating Holstein cows. J. Dairy Sci. 97:5742-5753. https://doi.org/10.3168/jds.2014 $-7963$. 
Fulton, W. R., T. J. Klopfenstein, and R. A. Britton. 1979. Adaptation to high concentrate diets by beef cattle. I. adaptation to corn and wheat diets. J. Anim. Sci. 49:775-784. https://doi.org/10 $.2527 /$ jas1979.493775x

Garrett, E. F., M. N. Pereira, K. V. Nordlund, L. E. Armentano, W. J. Goodger, and G. R. Oetzel. 1999. Diagnostic methods for the detection of subacute ruminal acidosis in dairy cows. J. Dairy Sci. 82:1170-1178. https://doi.org/10.3168/jds.S0022-0302(99)75340 $-3$.

Golder, H. M., J. M. Thomson, S. E. Denman, C. S. McSweeney, and I. J. Lean. 2018. Genetic markers are associated with the ruminal microbiome and metabolome in grain and sugar challenged dairy heifers. Front. Genet. 9:62. https://doi.org/10.3389/fgene.2018 .00062 .

Gröhn, Y. T., and M. L. Bruss. 1990. Effect of diseases, production, and season on traumatic reticuloperitonitis and ruminal acidosis in dairy cattle. J. Dairy Sci. 73:2355-2363. https://doi.org/10.3168/ jds.S0022-0302(90)78918-7.

Harvatine, K. J., and M. S. Allen. 2006a. Effects of fatty acid supplements on milk yield and energy balance of lactating dairy cows. J. Dairy Sci. 89:1081-1091. https://doi.org/10.3168/jds.S0022 -0302(06)72176-2.

Harvatine, K. J., and M. S. Allen. 2006b. Effects of fatty acid supplements on feed intake, and feeding and chewing behavior of lactating dairy cows. J. Dairy Sci. 89:1104-1112. https://doi.org/10 .3168/jds.S0022-0302(06)72178-6.

Harvatine, K. J., and M. S. Allen. 2006c. Effects of fatty acid supplements on ruminal and total tract nutrient digestion in lactating dairy cows. J. Dairy Sci. 89:1092-1103. https://doi.org/10.3168/ jds.S0022-0302(06)72177-4.

Hassanat, F., R. Gervais, C. Julien, D. I. Massé, A. Lettat, P. Y. Chouinard, H. V. Petit, and C. Benchaar. 2013. Replacing alfalfa silage with corn silage in dairy cow diets: Effects on enteric methane production, ruminal fermentation, digestion, $\mathrm{N}$ balance, and milk production. J. Dairy Sci. 96:4553-4567. https://doi.org/10 $.3168 /$ jds.2012-6480.

Higgins, J. P. T., S. G. Thompson, J. J. Deeks, and D. G. Altman. 2003. Measuring inconsistency in meta-analyses. BMJ 327:557560. https://doi.org/10.1136/bmj.327.7414.557.

Husson, A. F., J. Josse, and M. F. Husson. 2019. missMDA: Handling Missing Values with Multivariate Data Analysis, Version $1.141-39$.

Ikwuegbu, O. A., and J. D. Sutton. 1982. The effect of varying the amount of linseed oil supplementation on rumen metabolism in sheep. Br. J. Nutr. 48:365-375. https://doi.org/10.1079/ bjn19820120.

Jiang, F. G., X. Y. Lin, Z. G. Yan, Z. Y. Hu, G. M. Liu, Y. D. Sun, X. W. Li, and Z. H. Wang. 2017. Effect of dietary roughage level on chewing activity, ruminal $\mathrm{pH}$, and saliva secretion in lactating Holstein cows. J. Dairy Sci. 100:2660-2671. https://doi.org/10 $.3168 /$ jds.2016-11559.

Johnson, V. W., and J. D. Sutton. 1968. The continuous recording of the $\mathrm{pH}$ in the bovine rumen. Br. J. Nutr. 22:303-306. https://doi .org/10.1079/bjn19680036.

Josse, J., and F. Husson. 2016. missMDA: A package for handling missing values in multivariate data analysis. J. Stat. Softw. 70. https://doi.org/10.18637/jss.v070.i01.

Kirchgessner, M. 1987. Tierernährung, Leitfaden Für Studium, Beratung Und Praxis. DLG, Frankfurt, Germany.

Kleen, J. L., G. A. Hooijer, J. Rehage, and J. P. T. M. Noordhuizen. 2003. Subacute ruminal acidosis (SARA): A review. J. Vet. Med. A Physiol. Pathol. Clin. Med. 50:406-414. https://doi.org/10.1046/j .1439-0442.2003.00569.x.

Krause, K. M., and D. K. Combs. 2003. Effects of forage particle size, forage source, and grain fermentability on performance and ruminal $\mathrm{pH}$ in midlactation cows. J. Dairy Sci. 86:1382-1397. https:// doi.org/10.3168/jds.S0022-0302(03)73722-9.

Krause, K. M., D. K. Combs, and K. A. Beauchemin. 2002a. Effects of forage particle size and grain fermentability in midlactation cows. I. Milk production and diet digestibility. J. Dairy Sci. 85:19361946. https://doi.org/10.3168/jds.S0022-0302(02)74270-7.
Krause, K. M., D. K. Combs, and K. A. Beauchemin. 2002b. Effects of forage particle size and grain fermentability in midlactation cows. II. Ruminal pH and chewing activity. J. Dairy Sci. 85:1947-1957. https://doi.org/10.3168/jds.S0022-0302(02)74271-9.

Krause, K. M., D. K. Combs, and K. A. Beauchemin. 2003. Effects of increasing levels of refined cornstarch in the diet of lactating dairy cows on performance and ruminal pH. J. Dairy Sci. 86:1341-1353. https://doi.org/10.3168/jds.S0022-0302(03)73719-9.

Krause, K. M., and G. R. Oetzel. 2005. Inducing subacute ruminal acidosis in lactating dairy cows. J. Dairy Sci. 88:3633-3639. https: //doi.org/10.3168/jds.S0022-0302(05)73048-4.

Kronmal, R. A. 1993. Spurious correlation and the fallacy of the ratio standard revisited. 156:379-392. J. Royal Stat. Soc. A https://doi .org/10.2307/2983064.

Lane, G. T., C. H. Noller, V. F. Colenbrander, K. R. Cummings, and R. B. Harrington. 1968. Apparatus for obtaining ruminoreticular samples and the effect of sampling location on $\mathrm{pH}$ and volatile fatty acids. J. Dairy Sci. 51:114-116. https://doi.org/10.3168/jds .S0022-0302(68)86930-9.

Le Liboux, S., and J. L. Peyraud. 1998. Effect of forage particle size and intake level on fermentation patterns and sites and extent of digestion in dairy cows fed mixed diets. Anim. Feed Sci. Technol. 73:131-150. https://doi.org/10.1016/S0377-8401(98)00123-0.

Longuski, R. A., Y. Ying, and M. S. Allen. 2009. Yeast culture supplementation prevented milk fat depression by a short-term dietary challenge with fermentable starch. J. Dairy Sci. 92:160-167. https: //doi.org/10.3168/jds.2008-0990.

Macmillan, K., X. Gao, and M. Oba. 2017. Increased feeding frequency increased milk fat yield and may reduce the severity of subacute ruminal acidosis in higher-risk cows. J. Dairy Sci. 100:1045-1054. https://doi.org/10.3168/jds.2016-11337.

Maekawa, M., K. A. Beauchemin, and D. A. Christensen. 2002a. Chewing activity, saliva production, and ruminal $\mathrm{pH}$ of primiparous and multiparous lactating dairy cows. J. Dairy Sci. 85:1176-1182. https://doi.org/10.3168/jds.S0022-0302(02)74180-5.

Maekawa, M., K. A. Beauchemin, and D. A. Christensen. 2002b. Effect of concentrate level and feeding management on chewing activities, saliva production, and ruminal $\mathrm{pH}$ of lactating dairy cows. J. Dairy Sci. 85:1165-1175. https://doi.org/10.3168/jds.S0022 $-0302(02) 74179-9$.

Moher, D., A. Liberati, J. Tetzlaff, D. G. Altman, and The PRISMA Group. 2009. Preferred reporting items for systematic reviews and meta-analyses: The PRISMA statement. PLoS Med. 6:e1000097. https://doi.org/10.1371/journal.pmed.1000097.

Nocek, J. E. 1997. Bovine acidosis: Implications on laminitis. J. Dairy Sci. 80:1005-1028. https://doi.org/10.3168/jds.S0022 -0302(97)76026-0.

Nordlund, K. V., E. F. Garrett, and G. R. Oetzel. 1995. Herd-based rumenocentesis - A clinical approach to the diagnosis of subacute rumen acidosis. Compend. Contin. Educ. Pract. Vet. 17:48-56.

NRC (National Research Council). 2001. Nutrient Requirements of Dairy Cattle. 7th rev. ed. Natl. Acad. Press, Washington, DC.

Oba, M., and M. S. Allen. 2000a. Effects of brown midrib 3 mutation in corn silage on productivity of dairy cows fed two concentrations of dietary neutral detergent fiber: 1 . feeding behavior and nutrient utilization. J. Dairy Sci. 83:1333-1341. https://doi.org/10.3168/ jds.S0022-0302(00)75000-4.

Oba, M., and M. S. Allen. 2000b. Effects of brown midrib 3 mutation in corn silage on productivity of dairy cows fed two concentrations of dietary neutral detergent fiber: 2. Chewing activities. J. Dairy Sci. 83:1342-1349. https://doi.org/10.3168/jds.S0022 -0302(00)75001-6.

Penner, G. B., and M. Oba. 2009. Increasing dietary sugar concentration may improve dry matter intake, ruminal fermentation, and productivity of dairy cows in the postpartum phase of the transition period. J. Dairy Sci. 92:3341-3353. https://doi.org/10.3168/ jds.2008-1977.

R Core Team. 2018. R: A Language and Environment for Statistical Computing, Version 3.5.1. R Foundation for Statistical Computing, Vienna, Austria. 
Roman-Garcia, Y., R. R. White, and J. L. Firkins. 2016. Meta-analysis of postruminal microbial nitrogen flows in dairy cattle. I. Derivation of equations. J. Dairy Sci. 99:7918-7931. https://doi.org/10 $.3168 /$ jds.2015-10661.

Rook, J. A. F., and C. C. Balch. 1961. The effects of intraruminal infusions of acetic, propionic and butyric acids on the yield and composition of the milk of the cow. Br. J. Nutr. 15:361-369. https: //doi.org/10.1079/bjn19610046.

Russell, J. B. 1998. The importance of $\mathrm{pH}$ in the regulation of ruminal acetate to propionate ratio and methane production in vitro. J. Dairy Sci. 81:3222-3230. https://doi.org/10.3168/jds.S0022 $-0302(98) 75886-2$.

Rustomo, B., O. AlZahal, J. P. Cant, M. Z. Fan, T. F. Duffield, N. E. Odongo, and B. W. McBride. 2006a. Acidogenic value of feeds. II. Effects of rumen acid load from feeds on dry matter intake, ruminal $\mathrm{pH}$, fibre degradability and milk production in the lactating dairy cow. Can. J. Anim. Sci. 86:119-126. https://doi.org/10 .4141/A04-075.

Rustomo, B., O. AlZahal, N. E. Odongo, T. F. Duffield, and B. W. McBride. 2006b. Effects of rumen acid load from feed and forage particle size on ruminal $\mathrm{pH}$ and dry matter intake in the lactating dairy cow. J. Dairy Sci. 89:4758-4768. https://doi.org/10.3168/jds .S0022-0302(06)72525-5.

Schwarzer, G., J. R. Carpenter, and G. Rücker. 2015. Meta-Analysis with R. Springer, London, UK.

Silveira, C., M. Oba, W. Z. Yang, and K. A. Beauchemin. 2007. Selection of barley grain affects ruminal fermentation, starch digestibility, and productivity of lactating dairy cows. J. Dairy Sci. 90:2860-2869. https://doi.org/10.3168/jds.2006-771.

Stanton, T. L., L. R. Jones, R. W. Everett, and S. D. Kachman. 1992. Estimating milk, fat, and protein lactation curves with a test day model. J. Dairy Sci. 75:1691-1700. https://doi.org/10.3168/jds .S0022-0302(92)77926-0.

Sullivan, M. L., K. N. Grigsby, and B. J. Bradford. 2012. Effects of wet corn gluten feed on ruminal $\mathrm{pH}$ and productivity of lactating dairy cattle fed diets with sufficient physically effective fiber. J. Dairy Sci. 95:5213-5220. https://doi.org/10.3168/jds.2012-5320.

Sun, Y., and M. Oba. 2014. Effects of feeding a high-fiber byproduct feedstuff as a substitute for barley grain on rumen fermentation and productivity of dairy cows in early lactation. J. Dairy Sci. 97:1594-1602. https://doi.org/10.3168/jds.2013-7068.

Taylor, C. C., and M. S. Allen. 2005a. Corn grain endosperm type and brown midrib 3 corn silage: Site of digestion and ruminal digestion kinetics in lactating cows. J. Dairy Sci. 88:1413-1424. https://doi .org/10.3168/jds.S0022-0302(05)72809-5.

Taylor, C. C., and M. S. Allen. 2005b. Corn grain endosperm type and brown midrib 3 corn silage: Ruminal fermentation and N partitioning in lactating cows. J. Dairy Sci. 88:1434-1442. https://doi .org/10.3168/jds.S0022-0302(05)72811-3.

Taylor, C. C., and M. S. Allen. 2005c. Corn grain endosperm type and brown midrib 3 corn silage: Feeding behavior and milk yield of lactating cows. J. Dairy Sci. 88:1425-1433. https://doi.org/10 .3168/jds.S0022-0302(05)72810-1.

Templ, M., A. Kowarik, A. Alfons, and B. Prantner. 2019. VIM: Visualization and Imputation of Missing Values, Version 4.8.0 1-69.

Viechtbauer, W. 2019a. metafor: Meta-Analysis Package for R, Version 2.1-0 271.

Viechtbauer, W. 2019b. I ${ }^{2}$ for Multilevel and Multivariate Models. Accessed May 20, 2019. http://www.metafor-project.org/doku.php/ tips:i2_multilevel_multivariate.

Viechtbauer, W. 2019c. Model Selection Using the Glmulti and MuMIn Packages. Accessed May 20, 2019. http://www.metafor-project .org/doku.php/tips:model_selection_with_glmulti_and_mumin.

Voelker, J. A., and M. S. Allen. 2003a. Pelleted beet pulp substituted for high-moisture corn: 3 . Effects on ruminal fermentation, $\mathrm{pH}$, and microbial protein efficiency in lactating dairy cows. J. Dairy Sci. 86:3562-3570. https://doi.org/10.3168/jds.S0022-0302(03)73961 $-7$.
Voelker, J. A., and M. S. Allen. 2003b. Pelleted beet pulp substituted for high-moisture corn: 1. Effects on feed intake, chewing behavior, and milk production of lactating dairy cows. J. Dairy Sci. 86:35423552. https://doi.org/10.3168/jds.S0022-0302(03)73959-9.

White, R. R., M. B. Hall, J. L. Firkins, and P. J. Kononoff. 2017a. Physically adjusted neutral detergent fiber system for lactating dairy cow rations. I: Deriving equations that identify factors that influence effectiveness of fiber. J. Dairy Sci. 100:9551-9568. https: //doi.org/10.3168/jds.2017-12765.

White, R. R., M. B. Hall, J. L. Firkins, and P. J. Kononoff. 2017b. Physically adjusted neutral detergent fiber system for lactating dairy cow rations. II: Development of feeding recommendations. J. Dairy Sci. 100:9569-9584. https://doi.org/10.3168/jds.2017-12766.

Yang, W. Z., and K. A. Beauchemin. 2006a. Effects of physically effective fiber on chewing activity and ruminal $\mathrm{pH}$ of dairy cows fed diets based on barley silage. J. Dairy Sci. 89:217-228. https://doi .org/10.3168/jds.S0022-0302(06)72086-0.

Yang, W. Z., and K. A. Beauchemin. 2006b. Increasing the physically effective fiber content of dairy cow diets may lower efficiency of feed use. J. Dairy Sci. 89:2694-2704. https://doi.org/10.3168/jds .S0022-0302(06)72345-1.

Yang, W. Z., and K. A. Beauchemin. 2006c. Physically effective fiber: Method of determination and effects on chewing, ruminal acidosis, and digestion by dairy cows. J. Dairy Sci. 89:2618-2633. https:// doi.org/10.3168/jds.S0022-0302(06)72339-6.

Yang, W. Z., and K. A. Beauchemin. 2007a. Altering physically effective fiber intake through forage proportion and particle length: Chewing and ruminal pH. J. Dairy Sci. 90:2826-2838. https://doi .org/10.3168/jds.2007-0032.

Yang, W. Z., and K. A. Beauchemin. 2007b. Altering physically effective fiber intake through forage proportion and particle length: Digestion and milk production. J. Dairy Sci. 90:3410-3421. https: //doi.org/10.3168/jds.2006-818.

Yang, W. Z., and K. A. Beauchemin. 2009. Increasing physically effective fiber content of dairy cow diets through forage proportion versus forage chop length: Chewing and ruminal $\mathrm{pH}$. J. Dairy Sci. 92:1603-1615. https://doi.org/10.3168/jds.2008-1379.

Yang, W. Z., K. A. Beauchemin, and L. M. Rode. 2001. Effects of grain processing, forage to concentrate ratio, and forage particle size on rumen $\mathrm{pH}$ and digestion by dairy cows. J. Dairy Sci. 84:2203-2216. https://doi.org/10.3168/jds.S0022-0302(01)74667-X.

yWorks GmbH. 2019. YEd Graph Editor, Version 3.17.2. yWorks GmbH, Tübingen, Germany.

Zebeli, Q., J. Dijkstra, M. Tafaj, H. Steingass, B. N. Ametaj, and W. Drochner. 2008. Modeling the adequacy of dietary fiber in dairy cows based on the responses of ruminal $\mathrm{pH}$ and milk fat production to composition of the diet. J. Dairy Sci. 91:2046-2066. https: //doi.org/10.3168/jds.2007-0572.

Zebeli, Q., D. Mansmann, B. N. Ametaj, H. Steingaß, and W. Drochner. 2010. A model to optimise the requirements of lactating dairy cows for physically effective neutral detergent fibre. Arch. Anim. Nutr. 64:265-278. https://doi.org/10.1080/1745039X.2010.486603.

Zhang, S. Z., G. B. Penner, M. Abdelqader, and M. Oba. 2010a. Effects of feeding alfalfa hay on chewing, rumen $\mathrm{pH}$, and milk fat concentration of dairy cows fed wheat dried distillers grains with solubles as a partial substitute for barley silage. J. Dairy Sci. 93:3243-3252. https://doi.org/10.3168/jds.2009-3011.

Zhang, S. Z., G. B. Penner, W. Z. Yang, and M. Oba. 2010b. Effects of partially replacing barley silage or barley grain with dried distillers grains with solubles on rumen fermentation and milk production of lactating dairy cows. J. Dairy Sci. 93:3231-3242. https://doi.org/ 10.3168/jds.2009-3005.

\section{ORCIDS}

A. Mensching @ (t) htps://orcid.org/0000-0002-7302-9010 